\title{
Revised Leachate Pollution Index (r-LPI): A Tool to Quantify Pollution Potential of Landfill Leachate
}

Tribhuwan Singh Bisht ( $\square$ tribhuwanbisht12@gmail.com )

Indian Institute of Technology Delhi

\section{Dinesh Kumar}

North Delhi Municipal corporation

\section{Babu J. Alappat}

IIT Delhi: Indian Institute of Technology Delhi

\section{Research Article}

Keywords: Environmental Indices, Landfill Leachate, Municipal Solid Waste, Leachate Pollution, Fuzzy Analytic Hierarchy Process, Fuzzy Delphi Method

Posted Date: June 24th, 2022

DOI: https://doi.org/10.21203/rs.3.rs-1256027/v2

License: (c) (1) This work is licensed under a Creative Commons Attribution 4.0 International License. Read Full License 


\section{Revised Leachate Pollution Index (r-LPI): A Tool to Quantify Pollution Potential of 2 Landfill Leachate}

Tribhuwan Singh Bisht ${ }^{\mathrm{a}, *}$, Dinesh Kumar ${ }^{\mathrm{b}}$, Babu J. Alappat ${ }^{\mathrm{c}}$

${ }^{a}$ Research Scholar, Department of Civil Engineering, Indian Institute of Technology Delhi, Hauz Khas, New Delhi 110016, India (Corresponding Author). Email: tribhuwanbisht12@gmail.com

${ }^{b}$ Executive Engineer, North Delhi Municipal Corporation, New Delhi, 110002. Email: dineshkathpalia@gmail.com

' Professor, Department of Civil Engineering, Indian Institute of Technology, Delhi, Hauz Khas, New Delhi 110016, India. Email: alappat@civil.iitd.ac.in

\section{Abstract}

11 The leachate pollution index (LPI), a technique to quantify the contamination potential of landfill leachate, 12 was developed in 2003. Since then, numerous factors have challenged the relevance of LPI, including advancements in technology, the long-term reliability of these indicators, the incidence of emerging contaminants, and the LPI's efficacy. As a result, using LPI as a benchmark can lead to misinterpretation of the magnitude of leachate Pollution. To mitigate this, a revised leachate pollution index ( $\mathrm{r}$-LPI) was developed, which is more precise and robust in assessing the Pollution potential of landfill leachate. This article presents a comprehensive account of the development of r-LPI. The r-LPI was developed by incorporating fuzzy technique with a multi-criteria decision-making technique (MCDM), wherein the inputs from 60 experts in the field of the environment, specifically solid waste management, were acquired at different stages during its development. The fuzzy Delphi method (FDM) was used to select

21 the parameters. The fuzzy analytic hierarchy process (FAHP) was used to compute the relative weights of

22 the parameters and sub-index curves were used for normalization of the parameters. As an application,

23 the LPI and the r-LPI of the Bhalswa, Okhla, and Ghazipur landfills were calculated. The results indicate that r-LPI provides a more comprehensive prediction of leachate Pollution than the LPI.

\section{Graphical Abstract}




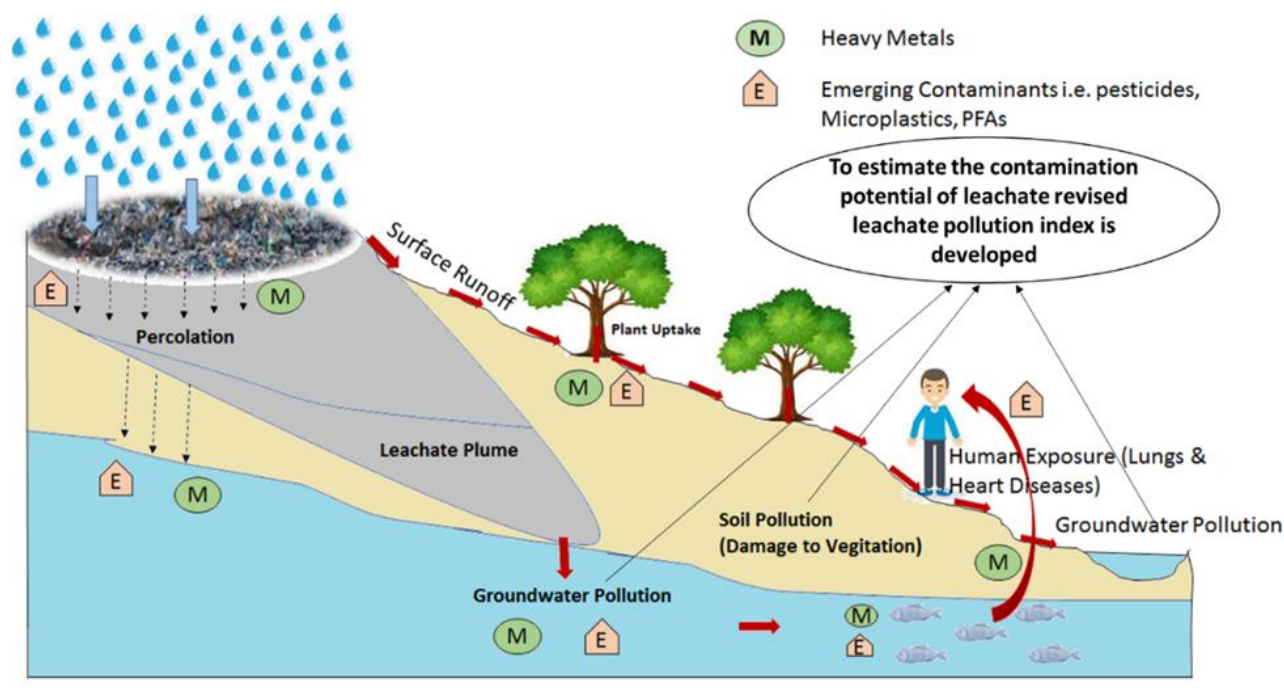

27 Keywords

Environmental Indices, Landfill Leachate, Municipal Solid Waste, Leachate Pollution, Fuzzy Analytic Hierarchy Process, Fuzzy Delphi Method

\section{Introduction}

31 The standard of living in developing countries is proliferating on a daily basis, leading to increased 32 production of municipal solid waste. Increased municipal solid waste (MSW) generation triggers significant environmental and economic issues during disposal. Landfilling is a relatively easy, low-cost, and commonly used MSW management technique when compared to other MSW management techniques such as composting and incineration (Luo et al. 2017; Renou et al. 2008; Schiopu and Gavrilescu 2010). Furthermore, particularly in developing countries, MSW segregation is an intrinsic task that is rarely practiced, rendering landfilling a deplorable yet undesirable option. It is estimated that approximately $95 \%$ of the MSW produced globally is dumped into landfills (Gao et al. 2015). The disposal of MSW in landfills inevitably causes toxic components to be released into the environment. Numerous factors contribute to the generation of landfill leachate, including physical, biochemical interactions, rainwater percolation, and high moisture content. Seasonal rain, on the other hand, exacerbates the problem by transporting leachate to nearby fields and residential areas (Al-Raisi et al. 2014). A multitude of factors, including waste composition, site hydrology, landfill age, and precipitation intensity, influence leachate characteristics (Abunama et al. 2018; Ahmed and Lan 2012). However, it is widely acknowledged 
that the most critical factor influencing leachate quality is the composition of the waste (Ehrig. 1983; Kang 46 et al. 2002; Kjeldsen et al. 2002; Lü et al. 2008; Öman and Junestedt 2008).

47 Despite the fact that modern landfills are engineered to mitigate the adverse effects of waste, leachate 48 generation continues to be a major concern for MSW landfills because it has the potential to contaminate 49 surface water and groundwater due to leachate dissipation through soil (Ashraf et al. 2013; Babau et al. 50 2021; Kjeldsen et al. 2002; Luo et al. 2019; Naveen et al. 2017; Yan et al. 2015). Thus, to comprehend the 51 impact of landfill leachate Pollution, a tool called the leachate pollution index was developed by Kumar 52 and Alappat (2003). It drew on the expertise of 80 waste management experts (Kumar and Alappat 53 2005b). Based on the LPI value, it is possible to assess whether landfill leachate necessitates immediate 54 intervention, as well as the treatment level. The LPI was developed as an increasing scale index. A higher 55 value indicates that leachate pollution has increased (Kumar and Alappat 2005a).

56 The LPI constitutes of 18 parameters: Lead, Chromium, Arsenic, mercury, zinc, nickel, copper, total iron, $57 \mathrm{pH}$, biological oxygen demand (BOD), chemical oxygen demand (COD), total coliform bacteria (TCB), 58 ammoniacal nitrogen, phenolic compounds, total Kjeldahl nitrogen (TKN), total dissolved solids (TDS), 59 cyanide, and chlorides (Kumar and Alappat 2003). The LPI value, which ranges from 5-100, reflects the 60 Pollution potential of landfill leachate based on multiple leachate pollution parameters at a given time. 

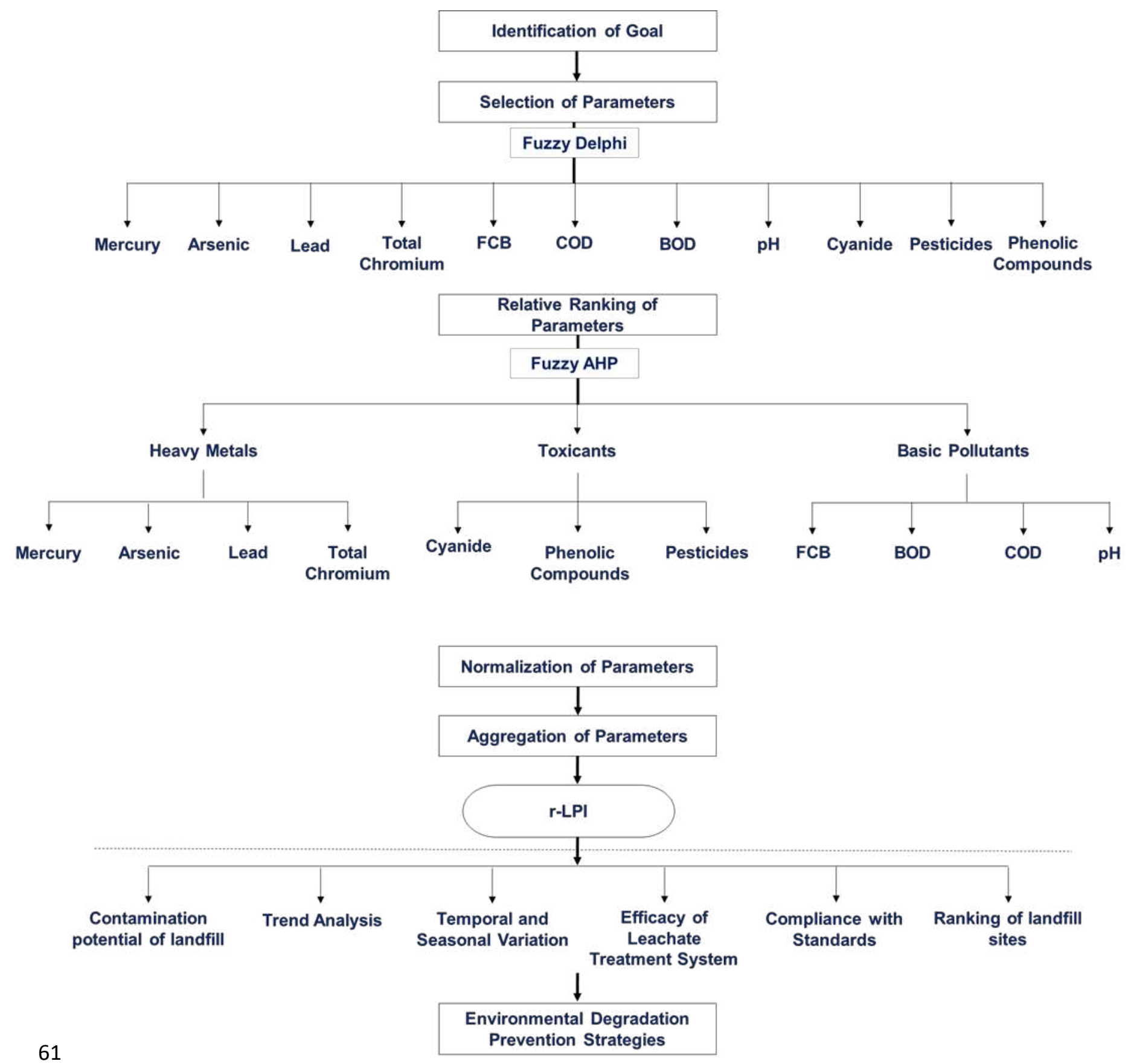

63 The LPI has been extensively used around the world to accomplish several goals, including comparing or 64 ranking municipal landfill sites (Aziz et al. 2010; Hussein et al. 2019; Joseph et al. 2020; Mishra et al. 2018;

65 Rani et al. 2020), estimating the pollution potential of landfill sites (Agbozu et al. 2015; Arunbabu et al. 66 2017; Kale et al. 2010; Lothe and Sinha 2017; Naveen et al. 2017; Sewwandi et al. 2013), assessing 67 temporal and seasonal variation of leachate quality (Chaudhary et al. 2020; Esakku et al. 2007), and 
assessing landfill leachate treatment system (Bhalla et al. 2014; Hossain et al. 2016). However, in recent times, the LPI has been criticized for its complexities, inadequacy in certain scenarios, and reliability (Mahler et al. 2020; Rajoo et al. 2020; Bisht et al. 2021).

The development of LPI entails soliciting expert's opinions. However, the Delphi technique utilized for the development of LPI was found out to be incapable of dealing with the uncertainty inherent in expert's opinions (Chang. 2013). Furthermore, the procedure used for the development of the index did not accurately represent the expert's viewpoints. As a result, there are inconsistencies in the weights allocated to the parameters (Bisht et al. 2021). There are 18 parameters in the LPI. The LPI value can be reported even if some of the parameters are missing. However, the missing parameters lead to errors in the overall LPI value.

In recent times, several new pollutants have been discovered or attained higher significance since its inception, such as pesticides, phthalate esters, perfluorinated compounds, pharmaceuticals, and personal care products (Baun et al. 2004, 2003; Eggen et al. 2010; Luo et al. 2019; Schwarzbauer et al. 2002; Slack et al. 2005). These parameters, even at low concentrations, may be hazardous to human health and the environment. The environmental-related laws and regulations might have been amended. As a result, the LPI's effectiveness and efficacy in the current scenario have been called into question. A recent assessment of the adequacy of the LPI in the current scenario was performed, and the study indicated that the LPI needs to be redeveloped (Bisht et al. 2021). As a result, the study aims to create a more robust and reliable index to more precisely predict the impact of leachate thus, the r-LPI was developed. The study extensively discusses the concept and systematic formulation of the r-LPI. Figure 1 illustrates the procedural flow chart for the formulation of the r-LPI. A comprehensive analysis of the r-LPI is provided in the subsequent sections. An assessment of the LPI and r-LPI is also provided in this study to determine the precision of $\mathrm{r}$-LPI.

\section{Methodology}

A composite index is a synthesis of several sources of information evaluated in or on a system to describe the system that is not explicitly observable. Taking into account both qualitative and quantitative characteristics of the index, judgments from a diverse expert panel were gathered via questionnaire surveys at various stages of index development as illustrated in Figure. 2.

The formulation primarily entails four phases 
1. Selection of Parameters

2. Determination of weights of selected parameters

3. Development of sub-index curves for the parameters

4. Selection of the appropriate aggregation function
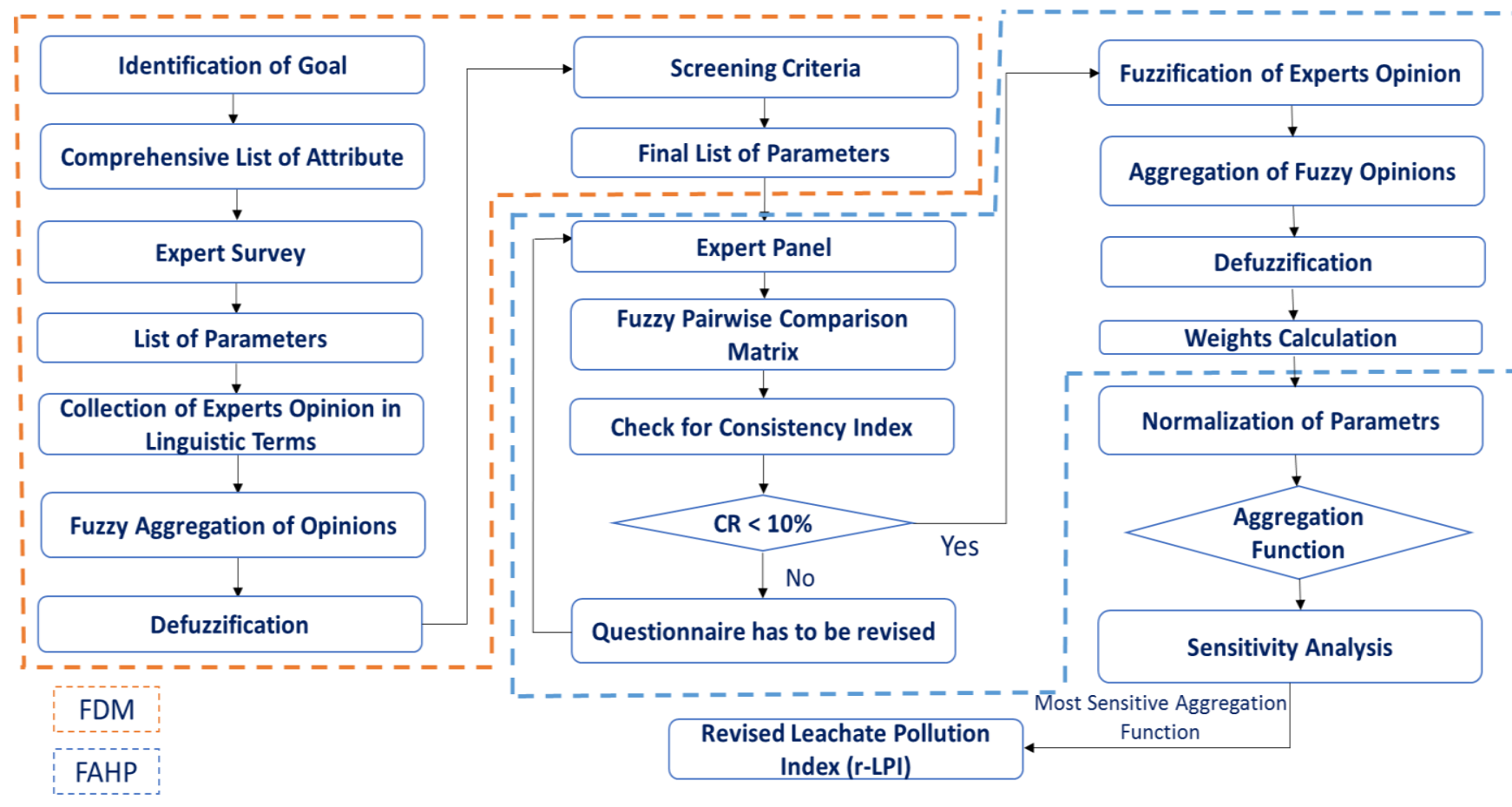

Figure. 2. Methodology for the formulation of r-LPI

\subsection{Selection of Parameters}

A comprehensive list of 62 parameters that have the potential to contaminate the leachate was put together based on the literature review and is specified in Table 1. The concentration of the parameters in the leachate in the available literature, as well as the effect of the parameters on the receiving environment and human health, were critical factors in parameter selection. The parameters were divided into two categories. Group 1 consisted of critical parameters that are either found in high concentrations in landfills or have the potential to cause an adverse effect on human health. Group 2 consisted of parameters that are present in leachate but not in such high concentrations to cause an adverse effect on

111 human health.

112 The fuzzy Delphi method (FDM) was used to select the parameters to be included in the r-LPI via an expert questionnaire survey. The FDM (Ishikawa 1993) incorporates fuzzy set theory (Zadeh 1965) into the 
114 standard Delphi method (Dalkey and Helmer 1962). The standard Delphi method is incapable of handling 115 the fuzziness and ambiguity inherent in expert opinions (Chang 2013). To address the shortcomings of the 116 conventional Delphi method, FDM was used for the screening of parameters.

Table1: List of Parameters Proposed for Inclusion in r-LPI

\begin{tabular}{|c|c|c|}
\hline \multicolumn{2}{|c|}{ LIST A PARAMETERS } & \multirow{2}{*}{$\begin{array}{l}\text { LIST B PARAMETERS } \\
\text { Cadmium }\end{array}$} \\
\hline Aluminum & Total Organic Carbon & \\
\hline Lead & Chemical Oxygen Demand & Phosphate \\
\hline Cobalt & Biological Oxygen Demand & Ortho Phosphorus \\
\hline Zinc & Benzene & Nitrate \\
\hline Nickel & Toluene & Organic Nitrogen \\
\hline Copper & 1,2 Dichloroethane & Dissolved Methane \\
\hline Arsenic & Dichloromethane & Total Volatile Acids \\
\hline Mercury & Naphthalene & Total Coliform Bacteria \\
\hline Chromium & Phenolic Compound & Fixed Solids \\
\hline Selenium & Ethyl Benzene & Hardness \\
\hline Chlorides & Delta BHC & Total Solids \\
\hline Fluoride & Xylenes & Volatile Suspended Solids \\
\hline Sulphate & Phthalate Esters & Total Suspended Solids \\
\hline Potassium & Chloroform & Turbidity \\
\hline Calcium & Acetone & Pesticides \\
\hline Magnesium & Cyanide & Perfluorinate Compounds \\
\hline \multirow[t]{2}{*}{ Total Iron } & Methyl Ethyl Ketone & Pharmaceuticals \& Personal \\
\hline & & Care Products (PPCPs) \\
\hline Sodium & Vinyl Chloride & \\
\hline Total Phosphorus & Fecal Coliform Bacteria & \\
\hline Manganese & $\mathrm{pH}$ & \\
\hline Ammoniacal Nitrogen & Conductivity & \\
\hline Total Kjeldahl Nitrogen & Total Dissolved Solids & \\
\hline Alkalinity & & \\
\hline
\end{tabular}


119 In the preliminary questionnaire, the panelists were briefed regarding the development of $r$-LPI. The range

120 of the concentration of parameters present in the landfill leachate, as well as their potential impact on

121 human health and the environment were discussed. They were subsequently asked to rate all the

122 parameters on a 9-point linguistic scale, as shown in table 2., based on their potential to cause an adverse

123 effect on human health and the environment.

Table 2- Triangular fuzzy numbers for nine-point scale

\begin{tabular}{lc}
\hline Linguistic Expressions & Fuzzy Number \\
\hline Extremely important & $(8,9,9)$ \\
Between very and extremely important & $(7,8,9)$ \\
Very Important & $(6,7,8)$ \\
Between moderate and Very important & $(5,6,7)$ \\
Moderately important & $(4,5,6)$ \\
Between very unimportant and & $(3,4,5)$ \\
Moderately important & \\
Very unimportant & $(2,3,4)$ \\
Between extremely and Very unimportant & $(1,2,3)$ \\
Extremely unimportant & $(1,1,1)$
\end{tabular}

125

126 For the preliminary questionnaire, a panel of 100 environmental experts were contacted in several phases

127 over the course of two months. All the panelists were experts in the field of environmental engineering, 128 predominantly in the field of waste management.

129 After the collection of fuzzified expert's opinions, equation 1 was used to aggregate expert's opinions.

$$
l_{i j}=\left(\prod_{k=1}^{k} l_{i j k}\right)^{1 / k}, m_{i j}=\left(\prod_{k=1}^{k} m_{i j k}\right)^{1 / k}, u_{i j}=\left(\prod_{k=1}^{k} u_{i j k}\right)^{1 / k}
$$

130 After fuzzy aggregation of expert's opinion, defuzzification of fuzzified values is accomplished using 131 equation 2 (Hsu et al. 2010; Wu and Fang 2011).

$$
F=\frac{L+M+U}{3}
$$


132 After defuzzification of the expert's opinion, the screening criteria for the parameters to be included in 133 the r-LPI were set at 7.0 based on the expert's opinion. Table 3 summarizes the preliminary questionnaire 134 findings.

Table 3: Defuzzified results of FDM

\begin{tabular}{ll}
\hline Leachate Parameter & Defuzzified Values \\
\hline Mercury & 7.984 \\
Lead & 7.762 \\
Arsenic & 7.844 \\
Total Chromium & 7.427 \\
BOD & 7.025 \\
COD & 7.053 \\
pH & 7.034 \\
FCB & 7.097 \\
Cyanide & 7.400 \\
Phenolic Compound & 7.025 \\
Pesticides & 7.043 \\
\hline
\end{tabular}

\subsection{Determination of Weights}

138 In this step, the relative value or contribution of an indicator to an index is reflected in the form of weight 139 assigned to it in the index. There are a multitude of weighting techniques available, each of which can 140 generate a unique set of overall results (OECD 2008). Although several composite indicators with equal 141 weighting parameters have been reported in the literature (Babcock 1970; Dojlido et al. 1994; Ott and

142 Thorn 1976). Assigning equal weights to all the parameters may result in an incoherent index structure 143 during the grouping and aggregation process (OECD 2008). The statistical weighting method, like principal 144 component analysis, may result in irrational weighing, with insignificant parameters securing higher 145 relative weights. Methods entailing expert opinions like AHP should make it easier to prioritize criteria 146 based on their importance.

147 Accounting for subjectivity in such dynamic decision-making necessitates the use of multi-criteria 148 decision-making techniques. AHP (Saaty 1977) is one of the most extensively used multi-criteria decision 149 making (MCDM) techniques in MSW management (Ekmekçioĝlu et al. 2010; Goulart Coelho et al. 2017; 
Soltani et al. 2015; Yap and Nixon 2015). Although AHP is designed to elicit expert knowledge, it is incapable of representing human thoughts as it involves human subjectivity, which induces a vagueness type of uncertainty and necessitates the use of decision-making under uncertainty (Kahraman et al. 2003). The standard AHP methodology is flawed because it seeks an exact value to articulate the decision maker's judgment in comparison to the alternative (Wang and Chen 2007). The AHP approach is often admonished because it employs an unbalanced scale of judgment and fails to account for the inherent ambiguity and uncertainty in the pairwise comparison (Deng 1999). A fuzzy AHP, synthesis of AHP, and fuzzy theory (Zadeh 1965) were introduced to resolve the shortcomings of traditional AHP (Van Laarhoven and Pedrycz 1983). It has been discovered that decision-makers are more precise and consistent in making interval judgments than when making fixed value judgments (Bozbura et al. 2007; Wang et al. 2016). This is due to their inability to express the fuzzy essence of the comparison process (Kahraman et al. 2003). Thus, in this study, relative weights of the parameters of the r-LPI were determined using FAHP.

There are various FAHP methods that can be used to calculate the weights of the r-LPI parameters. In order to obtain crisp weights from the fuzzy pairwise comparison matrices, there are three FAHP methods, namely, the extent analysis (Chang 1996), the fuzzy preference programming (FPP) based nonlinear method (Mikhailov 2003), and the logarithmic fuzzy preference programming (LFPP) (Wang and Chin 2011). All three FAHP methods were used to calculate and compare the weights of the r-LPI parameters and the results were reported elsewhere. From the comparative analysis, the LFPP method was chosen as its results were the most accurate (Bisht et al. 2022a).

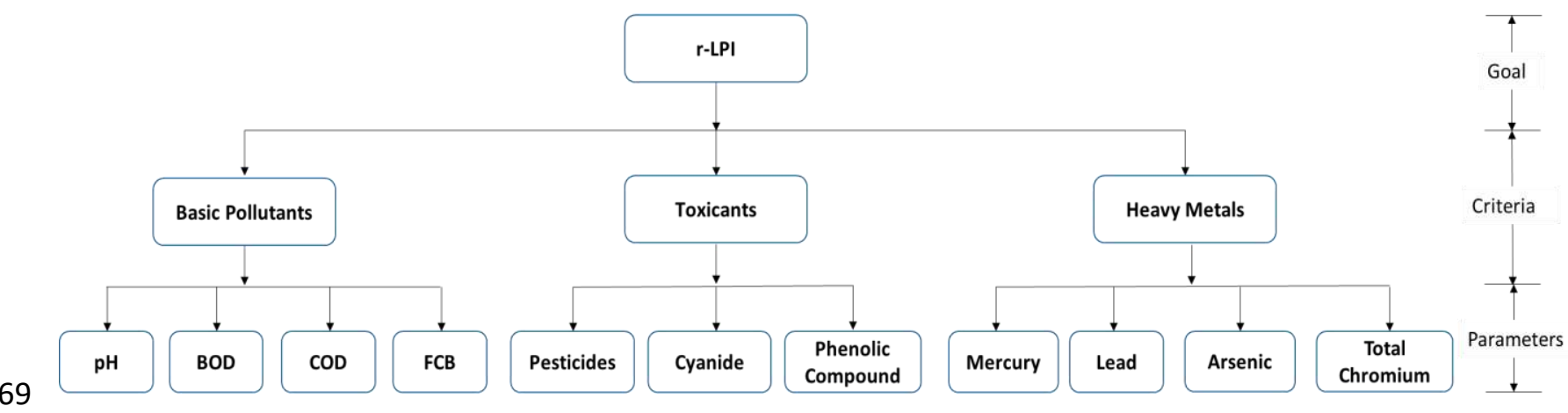

Figure. 3. Hierarchical structuring of the research problem

When using FAHP to rank alternatives, there are four key stages: goal identification, hierarchy development, creation of pairwise comparison matrices, and relative weight calculation. The hierarchical structure of the problem for ranking the parameters by FAHP is illustrated in Figure. 3 . In the second 
questionnaire, the panelists were asked to give their responses on a linguistic scale for the development of a fuzzy pairwise comparison matrix. All the experts that responded to the first questionnaire were consulted.

A linguistic scale was used to collect the responses of the experts. The concept of linguistic variables allows for the approximate representation of phenomena that are too complex or ill-defined to be expressed in a conventional, quantifiable form. Table 4 shows how the assessment of weights is represented by a linguistic component.

The parameters of the r-LPI were divided into 3 main criteria, namely:
a. Basic Pollutants
b. Heavy Metals
c. Toxicants

Table 4: Linguistic Variable for Pairwise Comparison

\begin{tabular}{|c|c|c|c|}
\hline Linguistic Scale & Fuzzy Number & Linguistic Scale & Fuzzy Reciprocal Scale \\
\hline Equally Important & $\mathbf{1}=(1,1,1)$ & Equally Unimportant & $\mathbf{1}=(1,1,1)$ \\
\hline Equal to Moderately & $\mathbf{2}=(1,2,3)$ & Equal to Moderately & $\mathbf{1} / \mathbf{2}=(1 / 3,1 / 2,1)$ \\
\hline Important & & Unimportant & \\
\hline Moderately Important & $\mathbf{3}=(2,3,4)$ & Moderately Unimportant & $\mathbf{1} / \mathbf{3}=(1 / 4,1 / 3,1 / 2)$ \\
\hline $\begin{array}{l}\text { Moderately to Strongly } \\
\text { Important }\end{array}$ & $4=(3,4,5)$ & $\begin{array}{l}\text { Moderately to Strongly } \\
\text { Unimportant }\end{array}$ & $\mathbf{1} / \mathbf{4}=(1 / 5,1 / 4,1 / 3)$ \\
\hline Strongly Important & $\mathbf{5}=(4,5,6)$ & Strongly Unimportant & $\mathbf{1} / \mathbf{5}=(1 / 6,1 / 5,1 / 4)$ \\
\hline $\begin{array}{l}\text { Strongly to Very } \\
\text { Strongly Important }\end{array}$ & $6=(5,6,7)$ & $\begin{array}{l}\text { Strongly to Very Strongly } \\
\text { Unimportant }\end{array}$ & $\mathbf{1 / 6}=(1 / 7,1 / 6,1 / 5)$ \\
\hline $\begin{array}{l}\text { Very Strongly } \\
\text { Important }\end{array}$ & $7=(6,7,8)$ & Very Strongly Unimportant & $\mathbf{1} / \mathbf{7}=(1 / 8,1 / 7,1 / 6)$ \\
\hline $\begin{array}{l}\text { Very Strongly } \\
\text { Important to Extremely } \\
\text { Important }\end{array}$ & $\mathbf{8}=(7,8,9)$ & $\begin{array}{l}\text { Very Strongly Important to } \\
\text { Extremely Unimportant }\end{array}$ & $\mathbf{1} / \mathbf{8}=(1 / 9,1 / 8,1 / 7)$ \\
\hline Extremely Important & $\mathbf{9}=(8,9,9)$ & Extremely Unimportant & $\mathbf{1} / \mathbf{9}=(1 / 9,1 / 9,1 / 8)$ \\
\hline
\end{tabular}

Firstly, the criteria were ranked relative to their importance to the goal, i.e. Pollution potential of landfill leachate. After that, a pairwise comparison of the parameters resulting from the preliminary survey was done based on the criteria in which they are categorized. The pairwise comparison matrix to record the responses of the experts is shown in Table 5. The experts were given four such pairwise comparison matrices to capture their responses.

Table 5: Pairwise comparison of the criteria based on their Pollution potential 


\begin{tabular}{cccc}
\hline $\begin{array}{c}\text { Pollution } \\
\text { Potential }\end{array}$ & Toxicants & Metals & $\begin{array}{c}\text { Basic } \\
\text { Pollutants }\end{array}$ \\
\hline Toxicants & 1 & $\mathrm{~A}_{12}$ & $\mathrm{~A}_{13}$ \\
Metals & $\mathrm{X}$ & 1 & $\mathrm{~A}_{21}$ \\
$\begin{array}{c}\text { Basic } \\
\text { Pollutants }\end{array}$ & $\mathrm{X}$ & $\mathrm{X}$ & 1 \\
\hline
\end{tabular}

193

194 In the subsequent steps, the parameters within the criteria were compared with each other based on 195 their potential to contaminate the landfill leachate. After the creation of the pairwise comparison matrix, 196 the responses of the experts were checked for consistency using the consistency ratio (CR), which was 197 computed using the consistency index (RI) and the random index (RI). The consistency ratio (CR), which 198 was calculated using equation (4).

$$
\text { Consistency Index, } C I=\frac{\lambda_{\max }-n}{n-1}
$$

199 Where $\mathrm{n}$ denotes the number of parameters being compared.

$$
\text { Consistency Ratio, } C R=\frac{C I}{R I}
$$

$200 \mathrm{Rl}$ is dependent on the value of $\mathrm{n}$. Responses with a CR up to 0.1 can be considered consistent, although 201 the value of 0 is considered optimal (Saaty 1977). Responses with a CR exceeding 0.1 were returned to 202 the panelists for revision attributable to logical discrepancies and inconsistent judgments in the pairwise 203 comparisons. The details of the responses received are depicted in Figure 4.

204 The relative weight of the criteria and sub-criteria was estimated using the LFPP. The LFPP method is 205 summarized below. 


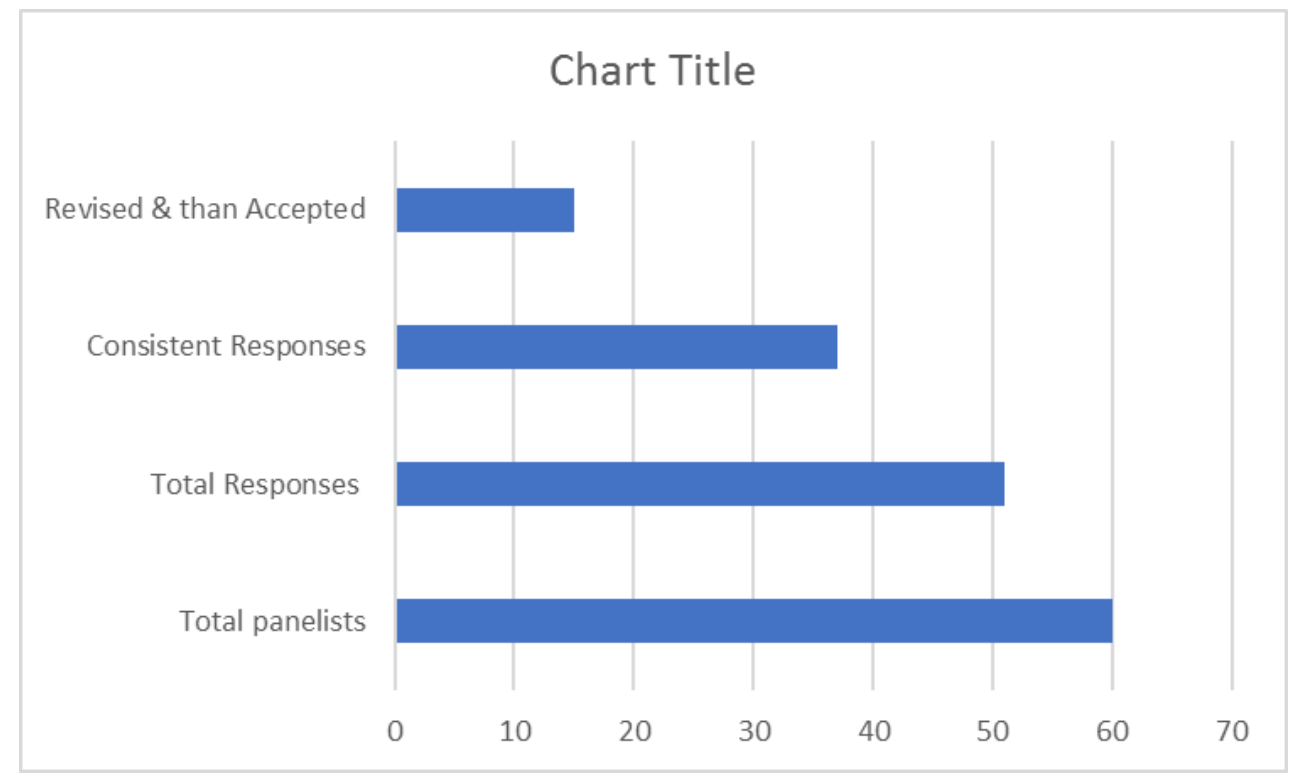

Figure. 4. Summary of the FAHP Response

209 In the above method, we take the logarithmic of the fuzzy pairwise comparison matrix using the 210 approximate equation:

$$
\ln \tilde{a}_{i j} \approx\left(\ln l_{i j}, \ln m_{i j}, \ln u_{i j}\right), l, j=1, \ldots \ldots, n .
$$

211 As a result, the membership function of a triangular fuzzy opinion can be defined as

$$
\mu_{i j}\left(\ln \left(\frac{w_{i}}{w_{j}}\right)\right)= \begin{cases}\frac{\ln \left(w_{i} / w_{j}\right)-\ln l_{i j}}{\ln m_{i j}-l_{i j}}, & \ln \left(\frac{w_{i}}{w_{j}} \leq \ln m_{i j}\right) \\ \frac{\ln u_{i j}-\ln \left(w_{i} / w_{j}\right)}{\ln u_{i j}-\ln u_{i j}}, & \ln \left(\frac{w_{i}}{w_{j}} \geq \ln m_{i j}\right)\end{cases}
$$

212 Where $\mu_{i j}\left(\ln \left(\mathrm{w}_{\mathrm{i}} / \mathrm{w}_{\mathrm{j}}\right)\right)$ denotes the degree of membership of $\ln \left(\mathrm{w}_{\mathrm{i}} / \mathrm{w}_{\mathrm{j}}\right)$ in the approximate fuzzy judgment $213 \operatorname{In} \tilde{a}_{i j}=\left(\ln l_{i j}, \ln m_{i j}, \ln u_{i j}\right)$. The crisp priority vector $\lambda=\min \left\{\mu_{i j}\left(\ln \left(w_{i} / w_{j}\right)\right) \mid I=1, \ldots \ldots ., n-1 ; j=i+1, \ldots \ldots ., n\right\}$ 214 can be used to optimize the minimum membership degree. The resulting model can be constructed as 215 follows:

216 Maximize $\lambda$

$$
\text { Subjected to }\left\{\begin{array}{c}
\mu_{i j}\left(\ln \left(\frac{w_{i}}{w_{j}}\right)\right) \geq \lambda, \quad i=1, \ldots \ldots, n-1 ; j=i+1, \quad \ldots \ldots ., n, \\
w_{i} \geq 0,
\end{array} \quad \begin{array}{c}
i=1, \quad \ldots \ldots, n,
\end{array}\right.
$$


Maximize $1-\lambda$

Subjected to

$$
\left\{\begin{array}{cc}
\ln w_{i}-\ln w_{j}-\lambda \ln \left(m_{i \mathrm{j}} / l_{i \mathrm{j}}\right) \geq \operatorname{lnl}_{\mathrm{ij}}, & i=1, \ldots \ldots, n-1 ; j=i+1, \quad \ldots \ldots \ldots, n, \\
-\ln w_{i}+\ln w_{j}-\lambda \ln \left(u_{i \mathrm{j}} / m_{i \mathrm{j}}\right) \geq-\operatorname{lnu}_{\mathrm{ij}}, & i=1, \ldots \ldots, n-1 ; j=i+1, \quad \ldots \ldots \ldots, n, \\
w_{i} \geq 0, & i=1, \quad \ldots \ldots, n
\end{array}\right.
$$

221 The above two equivalent models do not incorporate the normalization constraint $\sum_{i=1}^{n} w_{i}$. This is because 222 if the normalization constraint is used, the model would become computationally intensive. After the 223 model's priority is obtained; the normalization process can be done using the equation (8). Before 224 normalization, without sacrificing generality, we can assume $w_{i} \geq 1$ for all the $\mathrm{i}=1, \ldots . . ., \mathrm{n}$ such that $225 \ln w_{i} \geq 0$ for $\mathrm{i}=1, \ldots \ldots, \mathrm{n}$. The non-negative assumption for $\ln w_{i} \geq 0(\mathrm{i}=1, \ldots \ldots ., \mathrm{n})$ is not essential.

226 In general, the above model does not guarantee that the membership degree $\lambda$ will have a positive value.

227 This is because no weight exists within their support interval that can satisfy all the fuzzy judgments $\tilde{A}$.

228 That is, not all the inequalities $\ln w_{i}-\ln w_{j}-\lambda \ln \left(m_{i \mathrm{j}} / l_{i \mathrm{j}}\right) \geq \ln l_{i \mathrm{j}}$ or $-\ln w_{i}+\ln w_{j}-\lambda \ln \left(u_{i \mathrm{j}} / m_{i \mathrm{j}}\right) \geq$ $229-\ln \mathrm{u}_{i \mathrm{j}}$ may exist at the same time.

230 To prevent I from taking negative value, two non-negative deviation variables $\delta_{i j}$ and $\eta_{i j}$ for I $=1, \ldots \ldots ., \mathrm{n}-$ 2311 and $\mathrm{j}=\mathrm{i}+1, \ldots \ldots, \mathrm{n}$ are used, and the following objective function and constraints LFPP are achieved:

$$
\text { Mininize } J=(1-\lambda)^{2}+M \cdot \sum_{i=1}^{n-1} \sum_{j=i+1}^{n}\left(\delta_{i j}^{2}+\eta_{i j}^{2}\right)
$$

$$
\text { subjected to }\left\{\begin{array}{ccc}
x_{i}-x_{j}-\lambda\left(\mathrm{m}_{\mathrm{ij}} / \mathrm{l}_{\mathrm{ij}}\right)+\delta_{i \mathrm{j}} \leq \ln l_{i \mathrm{j}}, & i=1, \ldots \ldots, n-1 ; j=i+1, \ldots \ldots \ldots, n, \\
-x_{i}+x_{j}-\lambda\left(\mathrm{u}_{\mathrm{ij}} / \mathrm{m}_{\mathrm{ij}}\right)+\eta_{i \mathrm{j}} \leq-\ln u_{i \mathrm{j}}, & i=1, \ldots \ldots \ldots, n-1 ; j=i+1, \ldots \ldots \ldots, n, \\
\lambda, \mathrm{x}_{\mathrm{i}} \geq 0, & i=1, \ldots \ldots, n, \\
\delta_{i \mathrm{j}}, \eta_{i \mathrm{j}} \geq 0, & i=1, \ldots \ldots, n-1 ; j=i+1, \ldots \ldots, n,
\end{array}\right.
$$


233 Let $x_{i}(I=1,2, \ldots \ldots ., n)$ be the optimal solution to the model. The normalized priorities for fuzzy pairwise 234 comparison matrix $\tilde{A}=(\tilde{a} i j)_{n \times n}$ can be obtained as

$$
w_{i}=\frac{\exp \left(x_{i}\right)}{\sum_{j-1}^{n} \exp \left(x_{j}\right)}, \mathrm{i}=1, \ldots \ldots, \mathrm{n}
$$

235 The relative weights of the criteria and sub-criteria thus obtained are tabulated in Table 6

Table 6: Weights of the parameters of the r-LPI

\begin{tabular}{|c|c|c|c|c|}
\hline Criteria & $\begin{array}{l}\text { Criteria } \\
\text { Weight }\end{array}$ & Sub-Criteria & $\begin{array}{l}\text { Sub Criteria } \\
\text { Local Weights }\end{array}$ & $\begin{array}{l}\text { Global } \\
\text { Weights }\end{array}$ \\
\hline \multirow{4}{*}{ Toxicants } & \multirow{4}{*}{0.380} & Cyanide & 0.451 & 0.171 \\
\hline & & Pesticides & 0.299 & 0.114 \\
\hline & & Phenolic & & \\
\hline & & Compounds & $0 . \angle 51$ & כ \\
\hline \multirow{4}{*}{ Metals } & \multirow{4}{*}{0.363} & Mercury & 0.374 & 0.136 \\
\hline & & Lead & 0.255 & 0.093 \\
\hline & & Arsenic & 0.231 & 0.084 \\
\hline & & Total Chromium & 0.140 & 0.051 \\
\hline & & FCB & 0.305 & 0.078 \\
\hline Basic & & BOD & 0.278 & 0.071 \\
\hline \multirow[t]{2}{*}{ Pollutants } & ו & COD & 0.240 & 0.062 \\
\hline & & $\mathrm{pH}$ & 0.176 & 0.045 \\
\hline
\end{tabular}

237

238 2.3. Development of Normalized Curves

239 Composite indicators such as r-LPI is a unique index developed by the coalescence of chosen parameters 240 with varying relative weights. In this step, the r-LPI parameters were transformed into a uniform scale.

241 Only then can the parameters be aggregated. Normalization is a crucial step in the formulation of r-LPI, 242 as it transforms potentially incomparable parameters to a scale that can be compared. Ranking, 243 standardization, and categorical scaling are some of the recommended normalization methods (OECD 244 2008). There are various functions used for the normalization of sub-index curves. The commonly used 245 functions are the implicit function, which is inexpressible by a mathematical equation but can be plotted 246 on a graph, or an explicit function, which can be represented via a mathematical equation. A multitude of 
environmental indices has used these functions, like the water quality indices (Almeida et al. 2012; Brown et al. 1970; House and Newsome 1989), the Leachate pollution index (Kumar and Alappat 2003), and the i-index (Sebastian et al. 2019a).

The rating curves were drawn for each of the 11 parameters contributing to the development of $r$-LPI. The curves were engineered to reflect the contribution of the parameters to leachate Pollution as a function of their concentration. Consequently, the abscissa bounds were set in accordance with the concentration range of individual parameters. The equivalent normalized value, i.e. the level of leachate pollution which varied between 5-100 was indicated on the ordinate of the curve. The rating curves were so developed that at no point did they generate a null value, opening avenues for multiplicative aggregation techniques in the subsequent stages.

The leachate disposal standards and the concentration range of the parameters reported in landfill leachate were considered. Since all of the r-LPI parameters, except for $\mathrm{pH}$, indicate increased pollution with an increase in the concentration of the parameters, the graph exhibited a continually increasing trend. In the case of $\mathrm{pH}$, the graph was divided into three parts: as $\mathrm{pH}$ increases from 2 to 5 , the curve had a sharp negative slope, since higher $\mathrm{pH}$ values in this range correspond to less pollution potential, resulting in a lower normalized score. When the $\mathrm{pH}$ range was $5-9$, the curve was flat, correlating to a low normalized score, as it is the optimal range of $\mathrm{pH}$ for leachate. When $\mathrm{pH}$ varied from $9-14$, a sharply ascending curve was drawn because a higher $\mathrm{pH}$ value in this range correlates to high pollution potential, resulting in an increased normalized value. The curves were implicitly drawn because of their nonlinearity. Therefore, a mathematical equation cannot uniformly represent them. Even though mathematical functions have been set for uniform and non-uniform normalization curves (Swamee and Tyagi 2007), the behavior of different parameters cannot precisely be established, eventually leading to inconsistencies (Singh et al. 2008).

The curves thus developed were sent to a panel of 35 experts in the form of a third questionnaire. The panelists were then asked to develop the rating curves that represented the leachate pollution produced by various strengths or concentrations of the individual r-LPI pollutants. The panelists were provided information pertaining to the leachate disposal standards, the average concentration, and the range of the concentration of the pollutants to facilitate the development of the rating curves. In the third questionnaire, a $70 \%$ response rate was received. Although the panelist's views were generally agreed upon, a few panelists proposed slight changes. Almost $22 \%$ of the experts on the panel decided to modify the graph. An average curve was therefore developed, which incorporated all the changes that the panelists proposed for the final normalized curves. 
279 The final curves, as shown in figure 5, can be used to retrieve the sub-index values of the r-LPI parameters.

280

281

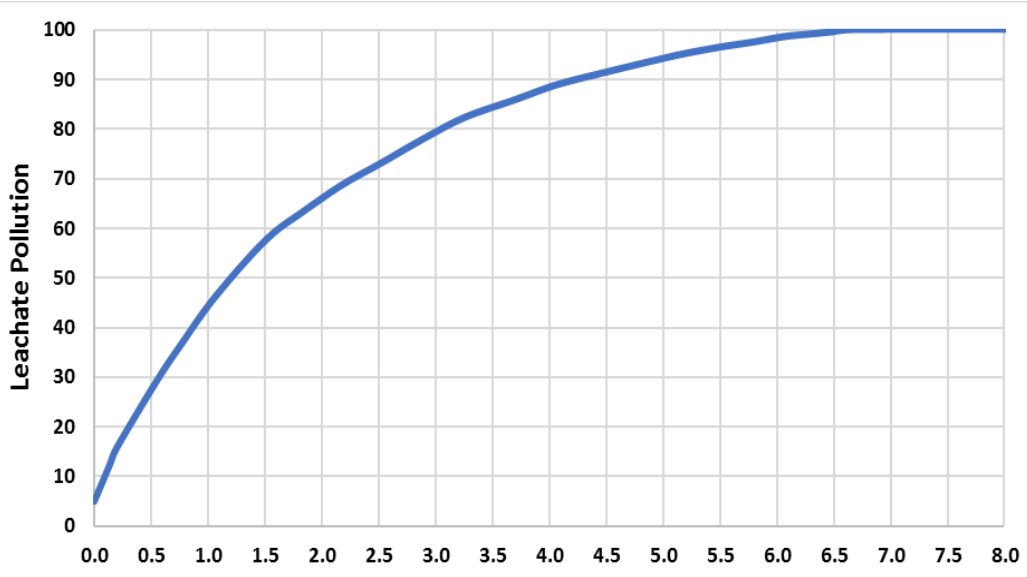

(a) Arsenic (mg/l)

282

283

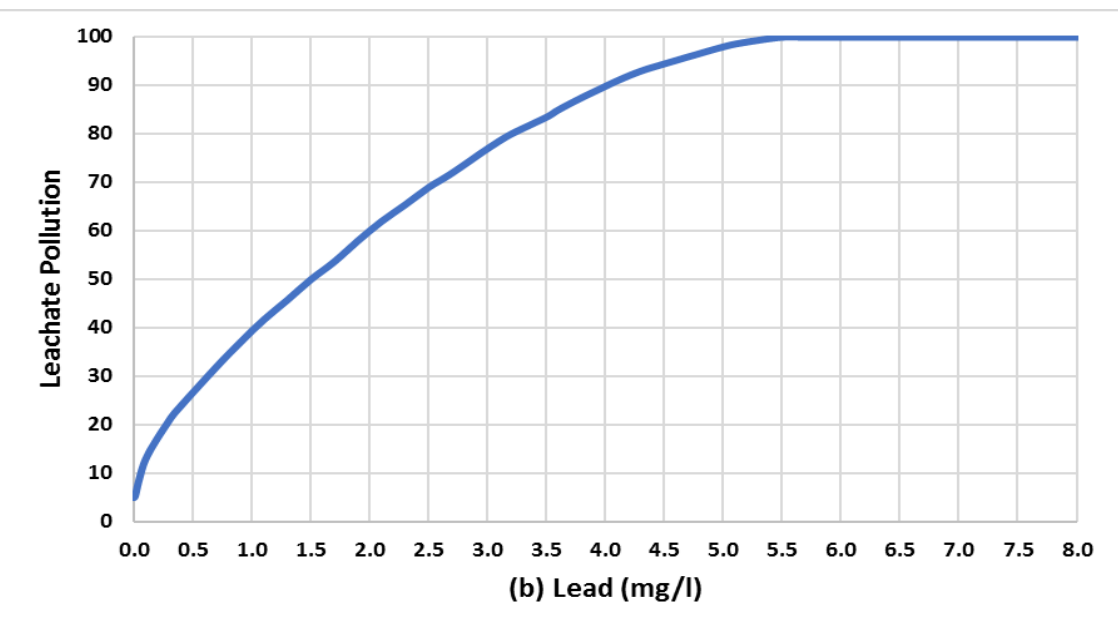

284

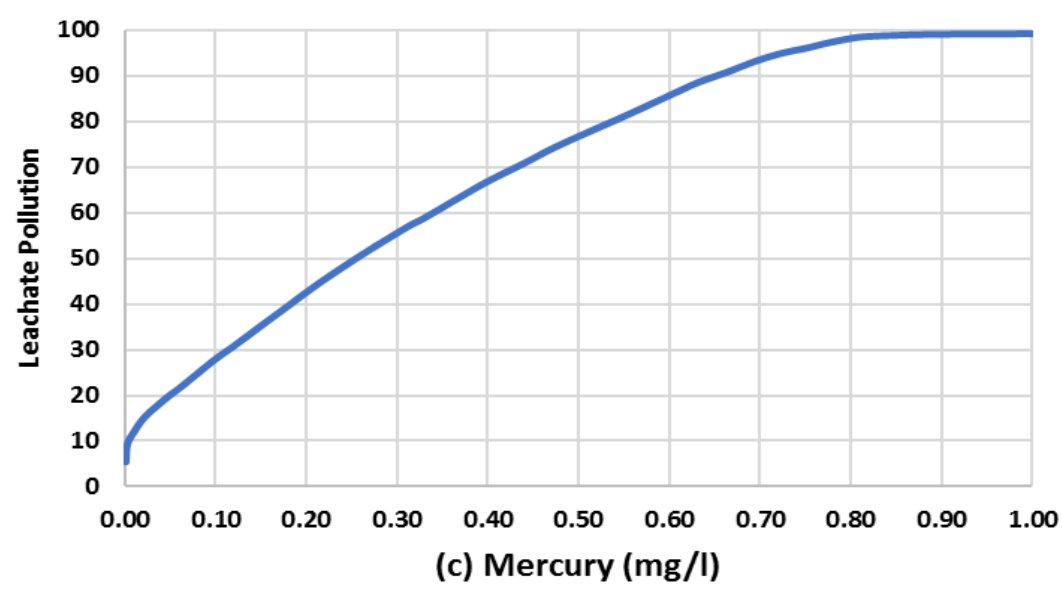




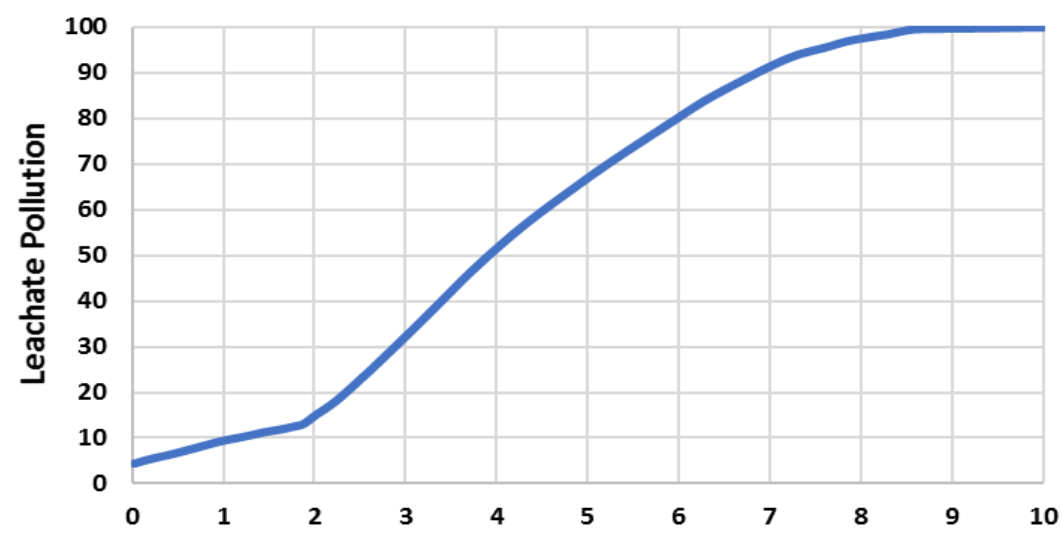

(d) Total Chromium ( $\mathrm{mg} / \mathrm{l}$ )

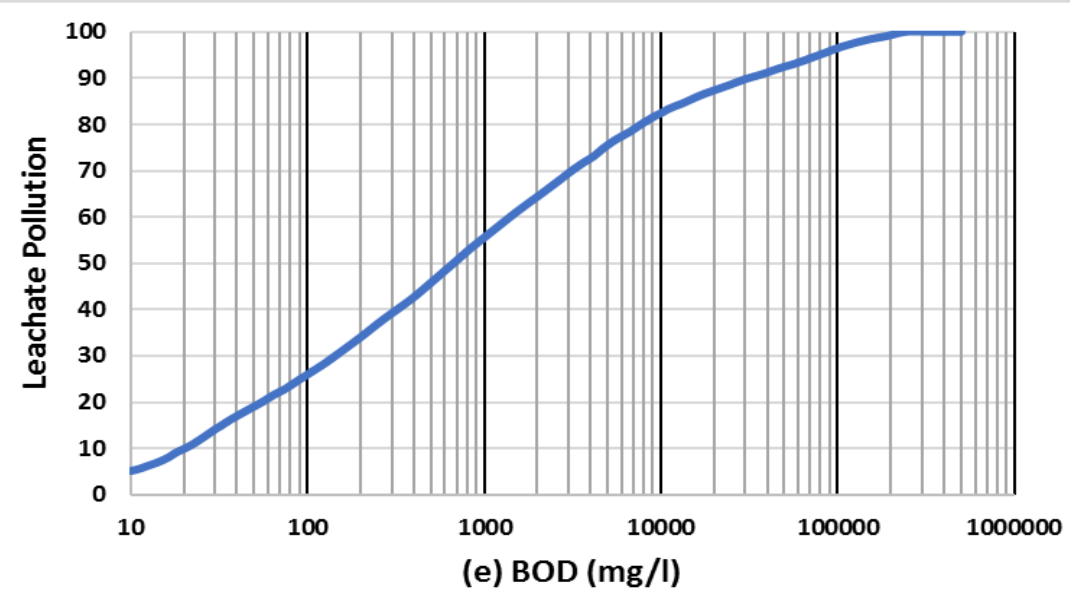

289

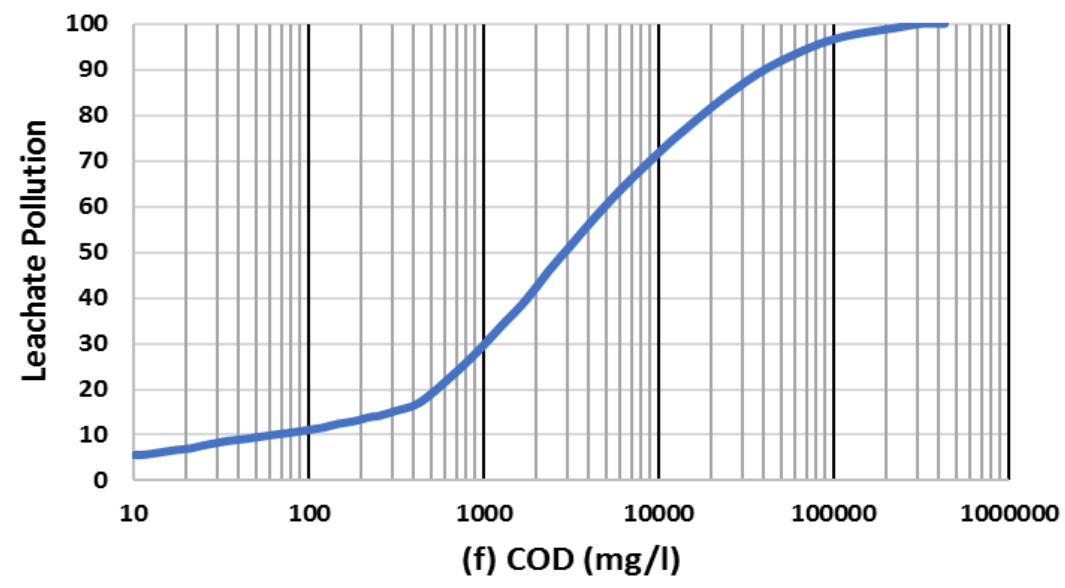




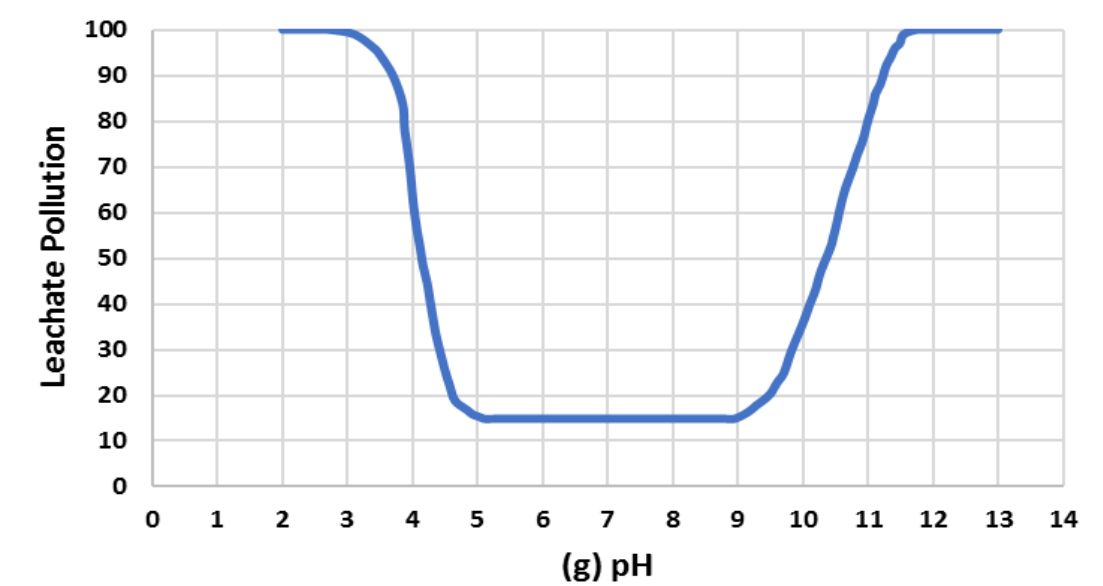

292

293

294

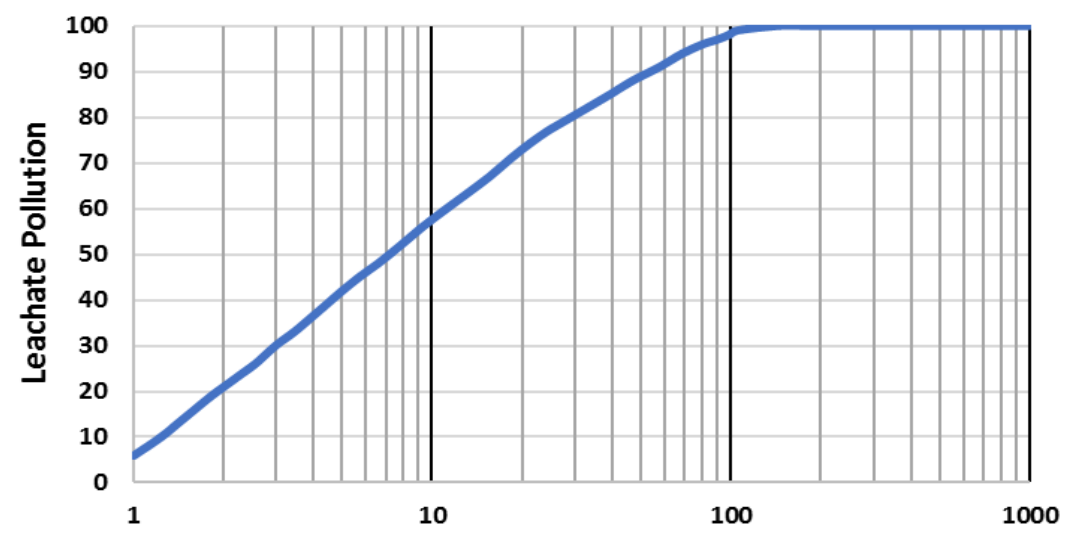

(h) Fecal Coliform Bacteria (MPN/100 ml)

295

296

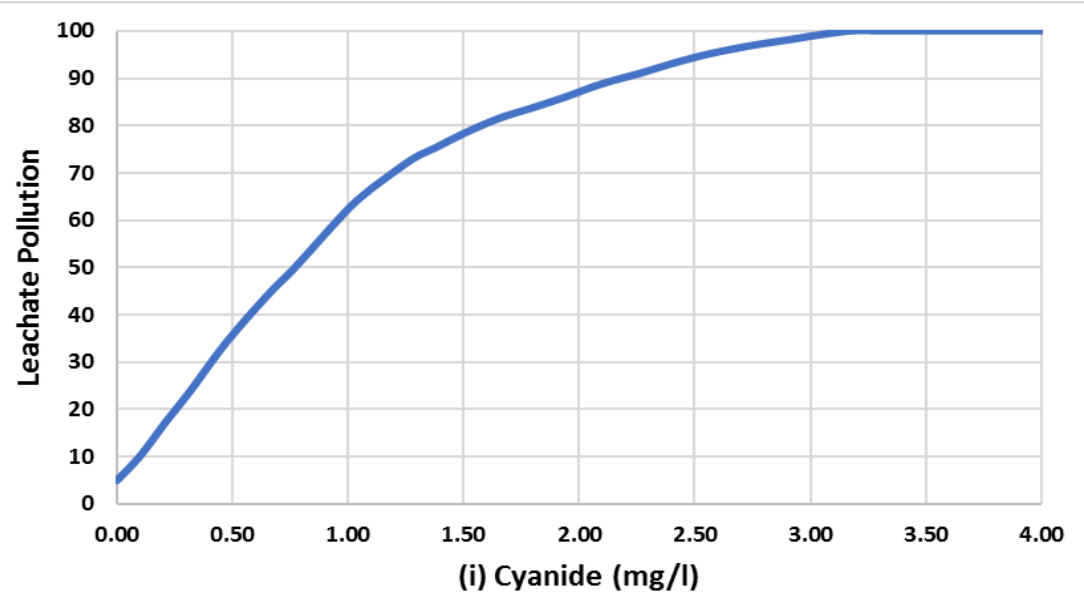



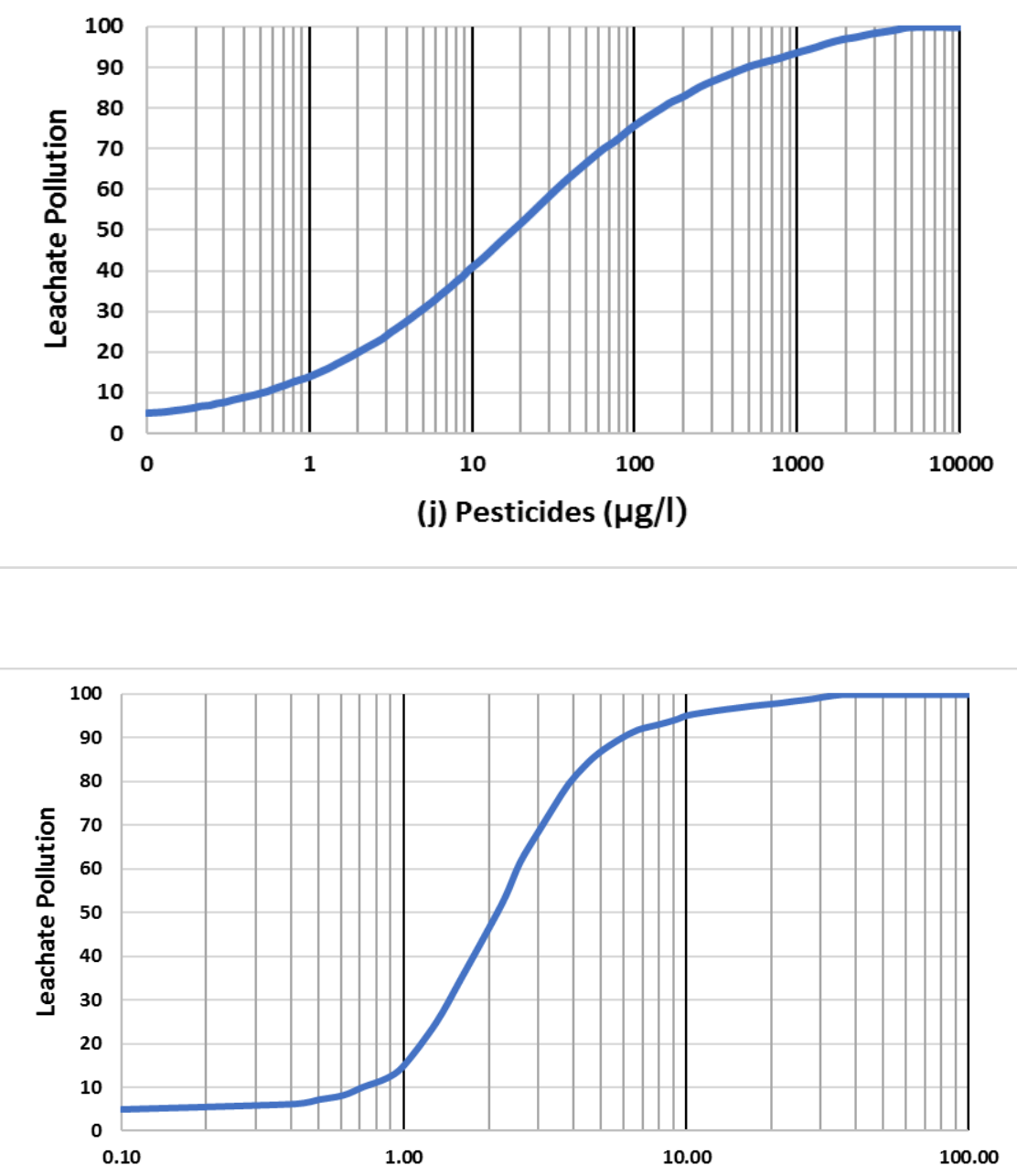

(k) Phenolic Compounds (mg/l)

Figure. 5. Normalization curve for (a) Arsenic (b) Lead (c) Mercury (d) Total Chromium (e) BOD (f) COD (g) ph (h) FCB (i) Cyanide (j) Pesticides (k) Phenolic Compounds.

\subsection{Aggregation of Sub-indices}

Aggregation is the final and one of the most important steps in the development of a composite indicator.

It is a process that involves the integration of the sub-indices to form a single composite index, like r-LPI, to quantify the Pollution potential of landfill leachate. During aggregation, there may be a loss of some

307 information. However, the information lost should not lead to misinterpretation of the result. Otherwise, 308 the utility of the indices will decline.

309 Several aggregation functions have been used for the development of environmental indices (OECD 2008;

310 Ott 1978). Additive aggregation methods (Brown et al. 1970; Kumar and Alappat 2004; Sebastian et al. $3112019 b$ ) and multiplicative aggregation methods (Almeida et al. n.d.; Dinius 1987;) are commonly used 
312 aggregation methods. Although there are no rules for the selection of an aggregation function, however, 313 the chosen aggregation function can have an impact on the usefulness of the indicator being developed.

Table 7: Sub-Index Values of the r-LPI Parameters

\begin{tabular}{lll}
\hline Parameter & $\begin{array}{l}\text { Concentration } \\
\text { (mg/L) }\end{array}$ & Sub-index value \\
\hline Cyanide & 0.03 & 8 \\
$\begin{array}{l}\text { Pesticides } \\
\text { Phenolic }\end{array}$ & 20 & 52 \\
Compounds & 0.25 & 6 \\
Mercury & 0.87 & 99 \\
Lead & 0.6 & 31 \\
Arsenic & 0.03 & 7 \\
Total Chromium & 3.22 & 40 \\
FCB & 13 & 64 \\
COD & 5653 & 63 \\
BOD & 2641 & 68 \\
pH & 8.2 & 15 \\
\hline
\end{tabular}

315 Note: All values are $u=i n \mathrm{mg} / \mathrm{L}$ except, $\mathrm{pH}$ and FCB.

$316 \quad{ }^{a}$ Assumed concentration values.

317

Most aggregation models encounter ambiguity, eclipsing, transparency, and rigidity as issues and problems caused by the abstraction of information and data (Jollands et al. 2003). Ambiguity or overestimation occurs if the aggregated value, even if the sub-indices are within limits, exceeds the permissible limits. In contrast, eclipsing occurs when, despite the fact that one or more sub-indices exceed the permissible value, the aggregated value is still within the permissible limits. Rigidity occurs when the addition of supplementary variables leads to inconsistencies in the aggregated value due to weakness in the aggregation function. The problem of transparency arises when information is lost during the process of disintegration of the index and when the aggregation function is insensitive and does not recognize the importance of the contributing sub-indices. All of these issues will eventually 
Table 8: $r$-LPI values for the study area using different aggregation functions

\begin{tabular}{|c|c|c|}
\hline Aggregation Function & Mathematical Form & r-LPI Values \\
\hline Unweighted Arithmetic & $i$ & 41.18 \\
\hline Weighted Arithmetic & $\frac{\sum_{1}^{n} W_{i} P_{i}}{\sum_{1}^{n} W_{i}}$ & 41.19 \\
\hline Root Sum Power Function (10) & $1 / 10$ & 99.48 \\
\hline Weighted root sum power (4) & $1 / 4$ & 65.01 \\
\hline Weighted root sum power (10) & $1^{1 / 10}$ & 81.30 \\
\hline Root Mean Square Function & $1 / 2$ & 50.56 \\
\hline $\begin{array}{l}\text { Weighted root sum square } \\
\text { function }\end{array}$ & $\frac{\left(\sum_{i=1}^{n} W_{i} P_{i}^{2}\right)^{0.5}}{\sum_{i=1}^{n} W_{i}}$ & 52.23 \\
\hline Maximum Operator & $\left.{ }_{1}, P_{2}, P_{3}-P_{n}\right)$ & 99 \\
\hline Minimum Operator & $\left.P_{2}, P_{3}-P_{n}\right)$ & 7 \\
\hline $\begin{array}{l}\text { Weighted ambiguity and } \\
\text { eclipsity free function }\end{array}$ & $2.5)^{0.4}$ & 56.26 \\
\hline $\begin{array}{l}\text { Subindex powered weight } \\
\text { function }\end{array}$ & & 14.96 \\
\hline $\begin{array}{l}\text { Unweighted Multiplicative } \\
\text { Function }\end{array}$ & $\left.T^{n} P_{i}\right)^{1 / n}$ & 28.16 \\
\hline Multiplicative & $\prod^{n} P_{i}^{W_{i}}$ & 26.42 \\
\hline $\begin{array}{l}\text { Square root unweighted } \\
\text { harmonic mean square function }\end{array}$ & $\sqrt{\frac{n}{\sum_{i=1}^{n} \frac{1}{P_{i}^{2}}}}$ & 12.43 \\
\hline
\end{tabular}


lead to a misinterpretation of leachate's pollution potential. The r-LPI will not suffer from the issue of

331 transparency and rigidity as expert opinions have been used to select the attributes. However, the issue

332 of ambiguity and eclipsing may persist. Thus, the selection of the aggregation function is crucial. However,

333 the selection of the same lacks scientific evidence. To redress this, sensitivity analysis was done, and the

334 most sensitive aggregation function was selected.

335 To determine the optimal aggregation function for r-LPI, a multitude of possible aggregation functions

336 were applied to an active landfill leachate characteristic. The analysis took into account leachate from an

337 active landfill site (Dhapa landfill) in Kolkata, India, as reported by De et al. (2016). The normalized

338 parameter value was deduced from the sub-index curves and is illustrated in Table 7.

339 Different weighted and unweighted functions of aggregating the r-LPI were investigated to ascertain an

340 eclipsing and ambiguity-free function. The r-LPI values resulting from the different aggregation functions

341 are shown in Table 8.

342

343

All unweighted aggregation functions were discarded based on the result obtained, as equal weighting

344 implies that all the sub-indices have the same weight. This can mask the lack of a statistical and analytical

345 basis for deciding weights. Furthermore, equal weighing may imply unequal weighting for the sub-indices,

346 since the sub-index with the most indicators would be given more weight in the overall index. Thus, the

347 unweighted aggregation will be ineffective in this analysis. Further, all the aggregation functions resulting

348 in the r-LPI value of more than 100 were also discarded as the practical range of $r$-LPI is $0-100$.

349 Furthermore, the majority of these functions show ambiguity. The sensitivity analysis was therefore

350 carried out with weighted arithmetic, Weighted root sum (power 4, 10), weighted root sum square

351 function, weighted ambiguity and eclipsity free function, and weighted multiplicative function since they

352 exhibit comparatively less ambiguity and eclipsing. Sensitivity analysis is a necessary step to gauge the

353 robustness and the transparency of the composite indicator (Ott 1978). It enables us to understand if the

354 variance in the output can be attributed to variation in the input, either qualitatively or quantitively. A

355 thorough investigation into the selection of appropriate aggregation functions was carried out and

356 reported elsewhere (Bisht et al. 2022b). As a result, the weighted arithmetic aggregation function was

357 found to exhibit comparatively less eclipsing than the weighted multiplicative and is also sensitive to

358 variations in the sub-index values and was thus used in the analysis (Bisht et al. 2022b).

$$
r-L P I=\frac{\sum_{i=1}^{n} w_{i} P_{i}}{\sum_{i=1}^{n} w_{i}}
$$


Where $P_{i}=$ Normalized value of the parameters

$360 \quad W_{i}=$ Corresponding weights

361

\section{Results and Discussion}

363

364

The r-LPI is made up of 11 parameters that were selected using FDM. FAHP was used to calculate the weightage of each parameter. The rating curves for the $11 \mathrm{r}$-LPI parameters were implicitly drawn at first and subsequently refined by the experts. These parameters were further classified into three categories i.e. heavy metals, basic pollutants, and toxicants. The r-LPI and the LPI had nine common parameters. Besides the nine common parameters, two additional parameters were added to the r-LPI; FCB and pesticides.

Pesticides pose a significant threat to the environment and human health due to their chronic toxicity, environmental persistence, carcinogenicity, and endocrine-disrupting characteristics (Man et al. 2018; Zhang et al 2017). Pesticides such as dichlorodiphenyltrichloroethane (DDTs), and hexacholorohexane ( $\mathrm{HCHs}$ ) were included in the Stockholm convention's list of 12 internationally prohibited persistent organic pollutants (POPs). Despite the fact that these pesticides have been banned, their residue has frequently been detected in landfill leachate (Lou et al. 2016; Wang et al. 2020; Xu et al. 2008). Due to their low water solubility, high fat solubility, and low vapor pressure these pesticides bioaccumulate and biomagnify in the ecosystem, making them even more hazardous to the environment and human health. One of the most troublesome contaminants, particularly in semi-aerobic landfills, is coliform bacteria (Aziz et al. 2010). The presence of fecal coliform is a major long-term issue (Mangimbulude et al. 2009). The presence of the bacteria can contaminate the groundwater and possess a potential health hazard (Grisey et al. 2010).

\subsection{LPI Case Study}

The LPI value for the landfills of Bhalswa, Okhla, and Ghazipur are shown in Table 9. Bhalswa landfill leachate was the most polluted with an LPI value of 29.20 followed by Ghazipur with an LPI value of 27.63. Okhla landfill leachate was the least polluted amongst the three with an LPI value of 25.78. In the LPI, heavy metals were given the highest weightage. However, the concentration of heavy metals in landfill leachate is fairly low (Christensen et al. 2001, 1994; Grosh 1998; Kjeldsen and Christophersen 2001). This is also evident in all the three landfills in our case study. Due to their high weights and low concentration resulting in low sub-index values, the overall LPI value of the three landfills has been pulled down. 
390 In the LPI, relatively high weightage was assigned to $\mathrm{pH}$. However, leachate generally has a $\mathrm{pH}$ in the range

391 of 4.5 to 9 (Christensen et al. 2001). Thus, leading to a low sub-index value and ultimately pulling down 392 the LPI value.

393

Table 9: LPI values for Bhalswa, Okhla, and Ghazipur landfills

\begin{tabular}{|c|c|c|c|c|c|c|c|c|c|c|}
\hline \multirow{2}{*}{$\begin{array}{l}\text { Leachate } \\
\text { Parameters }\end{array}$} & \multicolumn{3}{|c|}{ Pollutant Concentration* } & \multicolumn{3}{|c|}{ Sub-Index Value } & \multirow[t]{2}{*}{ Weights } & \multicolumn{3}{|c|}{ Overall Pollution Rating } \\
\hline & Bhalswa & Okhla & Ghazipur & Bhalswa & Okhla & Ghazipur & & Bhalswa & Okhla & Ghazipur \\
\hline COD & 5216 & 5972 & 7692 & 62 & 65 & 69 & 0.267 & 16.554 & 17.355 & 18.423 \\
\hline BOD & 2948 & 3994 & 7455 & 47 & 51 & 60 & 0.263 & 12.361 & 13.413 & 15.78 \\
\hline PC & 1.6 & 2.1 & 1.91 & 5 & 6 & 6 & 0.246 & 1.23 & 1.476 & 1.476 \\
\hline TCB & 20000 & 6000 & 1000 & 95 & 80 & 65 & 0.224 & 21.28 & 17.92 & 14.56 \\
\hline $\mathbf{L P I}_{\text {or }}$ & & & & & & & & 51.425 & 50.164 & 50.239 \\
\hline $\mathrm{pH}$ & 8.2 & 7.9 & 9.2 & 5 & 5 & 5 & 0.214 & 1.07 & 1.07 & 1.07 \\
\hline TKN & 1990 & 1913 & 1673 & 65 & 65 & 50 & 0.206 & 13.39 & 13.39 & 10.3 \\
\hline AN & 1997 & 721 & 829 & 100 & 20 & 88 & 0.198 & 19.8 & 3.96 & 17.424 \\
\hline TDS & 9235 & 5629 & 10000 & 18 & 10 & 20 & 0.195 & 3.51 & 1.95 & 3.9 \\
\hline Chloride & 9853 & 8573 & 9269 & 77 & 82 & 85 & 0.187 & 14.399 & 15.334 & 15.895 \\
\hline $\mathbf{L P I}_{\text {in }}$ & & & & & & & & 52.169 & 35.704 & 48.589 \\
\hline Total & & & & & & & & & & \\
\hline Chromium & 0.78 & 1.1 & 1.2 & 6 & 8 & 8 & 0.125 & 0.75 & 1 & 1 \\
\hline $\mathrm{Pb}$ & 0.2 & 0.35 & 0.84 & 5 & 6 & 8 & 0.123 & 0.615 & 0.738 & 0.984 \\
\hline $\mathrm{Hg}$ & 0.02 & 0.045 & 0.013 & 20 & 38 & 13 & 0.121 & 2.42 & 4.598 & 1.573 \\
\hline As & 1.53 & 2.23 & 1.79 & 5 & 6 & 5 & 0.119 & 0.595 & 0.714 & 0.595 \\
\hline Cy & 0.45 & 0.23 & 0.49 & 7 & 5 & 6 & 0.114 & 0.798 & 0.57 & 0.684 \\
\hline $\mathrm{Zn}$ & 5.3 & 10.32 & 8.13 & 5 & 6 & 5 & 0.11 & 0.55 & 0.66 & 0.55 \\
\hline $\mathrm{Ni}$ & 0.5 & 0.45 & 0.6 & 8 & 5 & 5 & 0.102 & 0.816 & 0.51 & 0.51 \\
\hline $\mathrm{Cu}$ & 0.54 & 0.23 & 0.46 & 5 & 5 & 5 & 0.098 & 0.49 & 0.49 & 0.49 \\
\hline $\mathrm{Fe}$ & 10.78 & 9.51 & 7.19 & 6 & 5 & 5 & 0.088 & 0.528 & 0.44 & 0.44 \\
\hline $\mathrm{LPI}_{\mathrm{hm}}$ & & & & & & & & 7.562 & 9.72 & 6.826 \\
\hline Overall LPI & & & $0.232 \mathrm{LPI}_{\mathrm{or}}$ & $0.257 \mathrm{LF}$ & in +0 . & $1 \mathrm{LPI}_{\mathrm{hm}}$ & & 29.295 & 25.874 & 27.728 \\
\hline
\end{tabular}

394 All values are in $\mathrm{mg} / \mathrm{L}$ except $\mathrm{pH}$ and $\mathrm{FCB}(\mathrm{MPN} / 100 \mathrm{~mL})$

395 *Source: Rani et al. (2020) 
397 In the LPI, very high weightage was assigned to BOD and COD. These pollutants, in comparison with others,

398 have relatively less potential to harm human health and the environment.

399 Thus, parameters with high weightage and low concentration would lead to low sub-index value, skewing 400 the overall pollution index to a lower value that inaccurately reflects the pollution impacts of the leachate 401 (Lothe and Sinha 2017). Thus, it can be inferred that the LPI cannot be used to calculate the true pollution 402 potential of landfill leachate.

\section{2. r-LPI Case Study}

405 The r-LPI value for the landfills of Bhalswa, Okhla, and Ghazipur are shown in Table 10. Ghazipur landfill 406 leachate was the most polluted with the r-LPI value of 46.29 followed by Okhla with the r-LPI value of 407 44.43. Bhalswa landfill leachate was the least polluted amongst the three with the r-LPI value of 38.97. 408 Organic waste made up the majority of waste received by all the three landfills in this study. This justifies 409 the fact that the basic pollutant has a major contribution to the overall r-LPI.

410 Toxicants had the highest weightage in the $\mathrm{r}-\mathrm{LPI}$, owing to the fact that the parameters in the toxicant 411 category are chronically toxic, carcinogenic, environmentally persistent, and have the tendency of 412 bioaccumulation. Basic pollutants, on the other hand, received the least weight because, in comparison, 413 they have relatively less potential to harm human health or the environment.

414 The concentration of heavy metals in landfill leachate is usually higher when the landfill is at a younger 415 stage due to high metal solubility induced by low $\mathrm{pH}$ generated by the production of organic acids 416 (Kulikowska and Klimiuk 2008). However, when the pH rises in later phases, the metal solubility decreases, 417 resulting in a rapid decrease in the concentration of heavy metals in leachate (Umar et al. 2010). The 418 heavy metals included in r-LPI are Arsenic, Chromium, lead, and mercury. Heavy metals pose a significant 419 threat to the environment and human health since they are extremely toxic, carcinogenic, and do not 420 degrade (Abunama et al. 2021; Hussein et al. 2021). Thus, in the r-LPI, heavy metals obtained moderate 421 weights. Similarly, the landfill leachate generally has neutral pH therefore in the r-LPI it has obtained the 422 least weightage. Furthermore, phenolic compounds have also been assigned moderate weights as the 423 concentration of phenolic compounds is generally low in landfills where waste is dumped in open space 424 as they are readily degradable under aerobic conditions (Umar et al. 2010; Yazıcı et al. 2012). 
425 Thus, the parameters with relatively low concentration in the landfill leachate have received moderate to

426 low weights in the r-LPI, thereby resolving the issue of lower individual pollution rating skewing the overall

427 index.

428

429

Table 10: r-LPI values for Bhalswa, Okhla, and Ghazipur landfills

\begin{tabular}{|c|c|c|c|c|c|c|c|c|c|c|}
\hline \multirow{2}{*}{$\begin{array}{l}\text { Leachate } \\
\text { Parameters }\end{array}$} & \multicolumn{3}{|c|}{ Pollutant Concentration* } & \multicolumn{3}{|c|}{ Sub-Index Value } & \multirow[t]{2}{*}{ Weightages } & \multicolumn{3}{|c|}{ Overall Pollution Rating } \\
\hline & Bhalswa & Okhla & Ghazipur & Bhalswa & Okhla & Ghazipur & & Bhalswa & Okhla & Ghazipur \\
\hline Cyanide & 0.45 & 0.23 & 0.49 & 35 & 19 & 44 & 0.451 & 15.785 & 8.569 & 19.844 \\
\hline Pesticides & - & - & - & - & - & - & 0.299 & - & - & - \\
\hline $\begin{array}{l}\text { Phenolic } \\
\text { Compounds }\end{array}$ & 1.6 & 2.1 & 1.91 & 36 & 53 & 45 & 0.251 & 9.036 & 13.303 & 11.295 \\
\hline $\mathrm{LPI}_{\text {tox }}$ & & & & & & & & 35.358 & 31.157 & 44.358 \\
\hline Mercury & 0.02 & 0.045 & 0.013 & 43 & 72 & 35 & 0.374 & 16.082 & 26.928 & 13.09 \\
\hline Lead & 0.2 & 0.35 & 0.84 & 21 & 23 & 37 & 0.255 & 5.355 & 5.865 & 9.435 \\
\hline Arsenic & 1.53 & 2.23 & 1.79 & 59 & 73 & 63 & 0.231 & 13.629 & 16.863 & 14.553 \\
\hline $\begin{array}{l}\text { Total } \\
\text { Chromium }\end{array}$ & 0.78 & 1.1 & 1.2 & 9 & 10 & 11 & 0.14 & 1.26 & 1.4 & 1.54 \\
\hline $\mathrm{LPI}_{\mathrm{hm}}$ & & & & & & & & 36.326 & 51.056 & 38.618 \\
\hline FCB & - & - & - & - & - & - & 0.305 & - & - & - \\
\hline COD & 5216 & 5927 & 7693 & 50 & 64 & 68 & 0.278 & 13.9 & 17.792 & 18.904 \\
\hline BOD & 2948 & 3994 & 7455 & 70 & 73 & 80 & 0.24 & 16.8 & 17.52 & 19.2 \\
\hline $\mathrm{pH}$ & 8.2 & 7.9 & 9.2 & 15 & 15 & 20 & 0.176 & 2.64 & 2.64 & 3.52 \\
\hline $\mathrm{LPI}_{\mathrm{bp}}$ & & & & & & & & 48.040 & 54.686 & \begin{tabular}{|l|}
59.978 \\
\end{tabular} \\
\hline LPI overall & & & $380 * \mathrm{LPI}_{\text {tox }}$ & $+0.363 * \mathrm{LF}$ & $\mathrm{I}_{\mathrm{hm}}+0$ & $257 * \mathrm{LPI}_{\mathrm{bp}}$ & & 38.969 & 44.427 & 46.288 \\
\hline
\end{tabular}

430 All values are in $\mathrm{mg} / \mathrm{L}$ except $\mathrm{pH}$ and $\mathrm{FCB}(\mathrm{MPN} / 100 \mathrm{~mL})$

431 *Source: Rani et al. (2020)

432

\section{4. Conclusion}

434 For almost two decades, LPI has been crucial in evaluating the Pollution potential of landfill leachate, but

435 it has inherent drawbacks. The Delphi technique, which was employed to formulate the LPI, is incapable

436 of coping with the inherent ambiguity in the decision-making process. Furthermore, the technique used 


\section{Availability of Data and Materials}

466 function.

\section{Declarations}

\section{Ethical Approval}

Not applicable

\section{Funding}

\section{Competing Interest}

for the development of the index did not accurately reflect the opinion of the experts. In the current scenario, LPI's relevance has been challenged by numerous issues, such as advancement in technology, consistency of these indicators over time, the emergence of new pollutants, and the efficacy of LPI. As a result, r-LPI has been developed using the fuzzy Delphi analytic hierarchy process. The r-LPI has overcome the aforementioned shortcomings and provided a more robust and reliable technique for quantifying the Pollution potential of landfill leachate on a scale of 5-100. A series of questionnaires were used to incorporate the opinions of 60 experts in the formulation of the r-LPI. FDM was used to select the 11 parameters to be included in r-LPI. The parameters chosen were categorized into three criteria: toxicants, heavy metals, and basic pollutants. The fuzzy AHP has been used to calculate the relative weights of the criteria and sub-criteria. The parameters have been aggregated using the weighted arithmetic aggregation

The LPI and the r-LPI value for Bhalswa, Okhla, and Ghazipur landfill leachate were computed, and the analysis was done. The case study reaffirms that r-LPI offers a more comprehensive and precise assessment of leachate Pollution risk. As a result, the r-LPI can be widely used for strategic planning, analysis of trends, and comparison of landfills, estimating the Pollution potential of specific landfill leachate, compliance with standards, and assessing the efficacy of leachate treatment methods.

No funding was received to assist with the preparation of this manuscript.

The authors have no competing interests to declare that are relevant to the content of this article.
All data generated or analyzed during this study are included in this published article 
467 Consent to Participate and/or Publish

468 Informed consent was obtained from all the experts involved in the study

\section{References}

472 Abunama T, Moodley T, Abualqumboz M, Kumari S, Bux F (2021) Variability of leachate quality and polluting potentials in light of Leachate Pollution Index (LPI) - A global perspective. Chemosphere 131119. https://doi.org/10.1016/j.chemosphere.2021.131119

Abunama T, Othman F, Younes MK (2019) Predicting sanitary landfill leachate generation in humid regions using ANFIS modeling. https://doi.org/10.1007/s10661-018-6966-y

Agbozu I, Oghama O, Odhikori J, (2015) Physico-Chemical Characterization and Pollution Index Manag. 19, 361. https://doi.org/10.4314/jasem.v19i3.4

Ahmed FN, Lan CQ (2012) Treatment of landfill leachate using membrane bioreactors: A review. Desalination 287, 41-54. https://doi.org/10.1016/j.desal.2011.12.012

Al-Raisi SAH, Sulaiman H, Suliman FE, Abdallah O, Abdul S, Al H, Sulaiman H, Suliman FE, Abdallah O, (2014) Assessment of heavy metals in leachate of an unlined landfill in the Sultanate of Oman. Int. J. Environ. Sci. Dev. 5, 60-63. https://doi.org/10.7763/IJESD.2014.V5.451

Almeida C, Oliva González S, Mallea M, González P (n.d.) A recreational water quality index using chemical, physical and microbiological parameters. https://doi.org/10.1007/s11356-012-0865-5

Arunbabu V, Indu KS, Ramasamy EV (2017) Leachate pollution index as an effective tool in determining the phytotoxicity of municipal solid waste leachate. Waste Manag. 68, 329-336. https://doi.org/10.1016/j.wasman.2017.07.012

Ashraf MA, Yusoff I, Yusof M, Alias Y (2013) Study of contaminant transport at an open-tipping waste disposal site. Environ. Sci. Pollut. Res. 20, 4689-4710. https://doi.org/10.1007/s11356-012-1423-x

Aziz HA, Umar M, Yusoff MS (2010) Variability of parameters involved in leachate pollution index and determination of LPI from four landfills in Malaysia. Int. J. Chem. Eng. 2010. https://doi.org/10.1155/2010/747953

Babcock LR (1970) A combined pollution index for measurement of total air pollution. J. Air Pollut. Control Assoc. 20, 653-659. https://doi.org/10.1080/00022470.1970.10469453

Babau AMC, Micle V,Damian GE, Sur IM Sustainable Ecological Restoration of Sterile Dumps Using 
Robinia pseudoacacia. Sustainability 2021,13, 14021. https://doi.org/10.3390/su132414021

Baun A, Ledin A, Reitzel LA, Bjerg PL, Christensen TH (2004) Xenobiotic organic compounds in leachates from ten Danish MSW landfills-chemical analysis and toxicity tests. Water Res. 38, 3845-3858. https://doi.org/10.1016/j.watres.2004.07.006

Baun A, Reitzel LA, Ledin A, Christensen TH, Bjerg PL (2003) Natural attenuation of xenobiotic organic compounds in a landfill leachate plume (Vejen, Denmark). J. Contam. Hydrol. 65, 269-291. https://doi.org/10.1016/S0169-7722(03)00004-4

Bhalla B, Saini M, Jha M (2014) Assessment of Municipal Solid Waste Landfill Leachate Treatment Efficiency by Leachate Pollution Index. Assessment 3, 8447-8454.

Bisht TS, Kumar DJ, Alappat B (2021a) Need for Reassessment of Environmental Indices. J. Hazardous, Toxic, Radioact. Waste 25, 1-7. https://doi.org/10.1061/(asce)hz.2153-5515.0000611

Bisht TS, Kumar DJ, Alappat B (2022a) Calculation of Three Fuzzy Analytic Hierarchy Process for Calculation of Weights of the Revised Leachate Pollution Index (r-LPI). Manuscript Submitted for Publication

Bisht TS, Kumar DJ, Alappat B (2022b) Identifying Optimal Aggregation Function for the Revised Leachate Pollution Index (r-LPI). Manuscript Submited for Publication

Bozbura FT, Beskese A, Kahraman C (2007) Prioritization of human capital measurement indicators using fuzzy AHP. Expert Syst. Appl. 32, 1100-1112. https://doi.org/10.1016/j.eswa.2006.02.006

Brown RM, McClelland NI, Deininger RA, Tozer RG (1970) A water quality index do we dare. Data Instrum. Water Qual. Manag.

Chang DY (1996) Applications of the extent analysis method on fuzzy AHP. Eur. J. Oper. Res. 95, 649655. https://doi.org/10.1016/0377-2217(95)00300-2

Chang H (2013) Perceptions of intellectual capital held by the supervisors of nursing divisions in hospitals in Taiwan 52, 1101-1115. https://doi.org/10.1108/MD-07-2013-0371

Chaudhary R, Nain P, Kumar A (2021) Temporal variation of leachate pollution index of Indian landfill sites and associated human health risk. Enviro Sci Pollut Res 28, 28391-28406. https://doi.org/10.1007/s11356-021-12383-1

Christensen TH, Kjeldsen P, Bjerg PL, Jensen DL, Christensen JB, Baun A, Albrechtsen HJ, Heron G (2001) Biogeochemistry of landfill leachate plumes. Appl. Geochemistry 16, 659-718. https://doi.org/10.1016/S0883-2927(00)00082-2

Christensen TH, Kjeldsen P, Hans-Jørgen A, Albrechtsen A, Heron G, Nielsen PH, Bjerg PL, Holm PE (1994) Attenuation of Landfill Leachate Pollutants in Aquifers. Crit. Rev. Environ. Sci. Technol. 24, 119- 
Dalkey N, Helmer O (1962) Helmer and Dalkey 1962 - Delphi.pdf.

De S, Maiti SK, Hazra T, Debsarkar A, Dutta A (2016) Leachate characterization and identification of dominant pollutants using leachate pollution index for an uncontrolled landfill site. Glob. J. Environ. Sci. Manag. 2, 177-186. https://doi.org/10.7508/gjesm.2016.02.008

Deng H, (1999) Multicriteria analysis with fuzzy pairwise comparison. Int. J. Approx. Reason. 21, 215231. https://doi.org/10.1016/S0888-613X(99)00025-0

Dinius SH (1987) Design of an Index of Water Quality. JAWRA J. Am. Water Resour. Assoc. 23, 833-843. https://doi.org/10.1111/j.1752-1688.1987.tb02959.x

Dojlido J, Raniszewski J, Woyciechowska J (n.d.) Water quality index applied to rivers in the vistula river basin in Poland.

Eggen T, Moeder M, Arukwe A (2010) Municipal landfill leachates: A significant source for new and emerging pollutants. Sci. Total Environ. 408, 5147-5157. https://doi.org/10.1016/j.scitotenv.2010.07.049

Ekmekçioĝlu M, Kaya T, Kahraman C (2010) Fuzzy multicriteria disposal method and site selection for

Ehrig HJ (1983) Quality and quantity of sanitary landfill leachate. Waste Manag. Res. 1, 53-68. https://doi.org/10.1177/0734242X8300100105 municipal solid waste. Waste Manag. 30, 1729-1736. https://doi.org/10.1016/j.wasman.2010.02.031

Esakku S, Karthikeyan OP, Joseph K, Nagendran R, Palanivelu K, Pathirana KPMN, Karunarathna AK, Basnayake BF (2007) Seasonal Variations in Leachate Characteristics from Municipal Solid Waste Dumpsites in India and Srilanka. Proc. Int. Conf. Sustain. Solid Waste Manag. 341-347.

Gao J, Oloibiri V, Chys M, Audenaert W, Bjorge, Yanling D, Herman H, Langenhove V, Demeestere K, Stijn, Van Hulle WH, (n.d.) The present status of landfill leachate treatment and its development trend from a technological point of view. https://doi.org/10.1007/s11157-014-9349-z

Goulart Coelho LM, Lange LC, Coelho HMG (2017) Multi-criteria decision making to support waste management: A critical review of current practices and methods. Waste Manag. Res. 35, 3-28. https://doi.org/10.1177/0734242X16664024

Grisey E, Belle E, Dat J, Mudry J, Aleya, L (2010) Survival of pathogenic and indicator organisms in groundwater and landfill leachate through coupling bacterial enumeration with tracer tests. Desalination 261, 162-168. https://doi.org/10.1016/J.DESAL.2010.05.007

Grosh CJ (1998) Analysis of Florida MSW landfill leachate quality. Environ. Eng. 108. 
Hossain D, Mostazi MA, Ferdaush J (2016) Computation Of Leachate Pollution Index OF Matuail Landfill. Int. J. Civ. Eng. 3, 1-9.

House MA, Newsome DH (1989) Water quality indices for the management of surface water quality. Water Sci. Technol. 21, 1137-1148. https://doi.org/10.1016/b978-1-4832-8439-2.50112-7

Hsu YL, Lee CH, Kreng VB (2010) The application of Fuzzy Delphi Method and Fuzzy AHP in lubricant regenerative technology selection. Expert Syst. Appl. 37, 419-425. https://doi.org/10.1016/j.eswa.2009.05.068

Hussein M, Yoneda K, Zaki ZM, Othman NA, Amir A (2019) Leachate characterizations and pollution indices of active and closed unlined landfills in Malaysia. Environ. Nanotechnology, Monit. Manag. 12, 100232. https://doi.org/10.1016/i.enmm.2019.100232

Hussein M, Yoneda K, Mohd-Zaki Z, Amir A, Othman N (2021) Heavy metals in leachate, impacted soils and natural soils of different landfills in Malaysia: An alarming threat. Chemosphere 267, 128874. https://doi.org/10.1016/J.CHEMOSPHERE.2020.128874

Ishikawa A (1993) The Max-Min Delphi method and fuzzy Delphi method via fuzzy integration 55, 241253.

Jollands N, Lermit J, Patterson M (2003) The usefulness of aggregate indicators in policy making and evaluation: a discussion with application to eco-efficiency indicators in New Zealand 39.

Joseph SMR, Wijekoon P, Dilsharan B, Punchihewa ND, Athapattu BCL, Vithanage M (2020) Anammox, biochar column and subsurface constructed wetland as an integrated system for treating municipal solid waste derived landfill leachate from an open dumpsite. Environ. Res. 189, 109880. https://doi.org/10.1016/j.envres.2020.109880

Kahraman C, Cebeci U, Ulukan Z (2003) Multi-criteria supplier selection using fuzzy AHP. Logist. Inf. Manag. 16, 382-394. https://doi.org/10.1108/09576050310503367

Kale SS, Kadam AK, Kumar S, Pawar NJ (2010) Evaluating pollution potential of leachate from landfill site, from the Pune metropolitan city and its impact on shallow basaltic aquifers. Environ. Monit. Assess. 162, 327-346. https://doi.org/10.1007/s10661-009-0799-7

Kang KH, Shin HS, Park H (2002) Characterization of humic substances present in landfill leachates with different landfill ages and its implications. Water Res. 36, 4023-4032. https://doi.org/10.1016/S0043-1354(02)00114-8

Kjeldsen P, Barlaz MA, Rooker AP, Baun A, Ledin A, Christensen TH (2002) Present and Long-Term Composition of MSW Landfill Leachate: A Review. Crit. Rev. Environ. Sci. Technol. 32, 297-336. https://doi.org/10.1080/10643380290813462 
Kjeldsen P, Christophersen M (2001) Composition of leachate from old landfills in Denmark. Waste Manag. Res. 19, 249-256. https://doi.org/10.1177/0734242X0101900306

Kumar D, Alappat BJ (2005a) Evaluating leachate contamination potential of landfill sites using leachate pollution index. Clean Technol. Environ. Policy 7, 190-197. https://doi.org/10.1007/s10098-004$\underline{0269-4}$

Kulikowska D, Klimiuk E (2008) The effect of landfill age on municipal leachate composition. Bioresour. Technol. 99, 5981-5985. https://doi.org/10.1016/j.biortech.2007.10.015

Kumar D, Alappat BJ (2005b) Analysis of leachate pollution index and formulation of sub-leachate pollution indices. Waste Manag. Res. 23, 230-239. https://doi.org/10.1177/0734242X05054875

Kumar D, Alappat BJ (2004) Selection of the Appropriate Aggregation Function for Calculating Leachate Pollution Index. Pract. Period. Hazardous, Toxic, Radioact. Waste Manag. 8, 253-264. https://doi.org/10.1061/(asce)1090-025x(2004)8:4(253)

Kumar D, Alappat BJ (2003) A technique to quantify landfill leachate pollution. Proc., 9th Int. Waste Manag. Landfill Symp. 400.

Lothe AG, Sinha A (2017) Development of model for prediction of Leachate Pollution Index (LPI) in absence of leachate parameters. Waste Manag. https://doi.org/10.1016/j.wasman.2016.07.026

Lou Z, Li A, Tai J, Yuan W, Zhu N, Zhao Y (2016) Distribution pattern and the risks of OPCs, PHAs and PCBs in aged refuses from landfill. Waste Manag. 55, 330-335. https://doi.org/10.1016/J.WASMAN.2016.03.018

Lü F, Zhang H, Chang CH, Lee DJ, He PJ, Shao LM, Su A (2008) Dissolved organic matter and estrogenic potential of landfill leachate. Chemosphere 72, 1381-1386. https://doi.org/10.1016/j.chemosphere.2008.04.015

Luo H, Cheng Y, He D, Yang EH (2019) Review of leaching behavior of municipal solid waste incineration (MSWI) ash. Sci. Total Environ. https://doi.org/10.1016/j.scitotenv.2019.03.004

Luo H, Wu Y, Zhao A, Kumar A, Liu Y, Cao B, Yang EH (2017) Hydrothermally synthesized porous materials from municipal solid waste incineration bottom ash and their interfacial interactions with chloroaromatic compounds. J. Clean. Prod. 162, 411-419. https://doi.org/10.1016/j.jclepro.2017.06.082

Man YB, Chow KL, Cheng Z, Kang Y, Wong MH (2018) Profiles and removal efficiency of organochlorine pesticides with emphasis on DDTs and $\mathrm{HCHs}$ by two different sewage treatment works. Environ. Technol. Innov. 9, 220-231. https://doi.org/10.1016/J.ETI.2017.12.004

Mangimbulude JC, Breukelen BMV, Krave AS, Straalen NMV, Röling WFM (2009) Seasonal dynamics in 
leachate hydrochemistry and natural attenuation in surface run-off water from a tropical landfill. Waste Manag. 29, 829-838. https://doi.org/10.1016/J.WASMAN.2008.06.020

Mahler CF, De Almeida JR, Bassin JP (2020) Index to evaluate closed landfills based on leachate parameters. Detritus 10, 200-211. https://doi.org/10.31025/2611-4135/2020.13948

Mikhailov L (2003) Deriving priorities from fuzzy pairwise comparison judgements. Fuzzy Sets Syst. 134, 365-385. https://doi.org/10.1016/S0165-0114(02)00383-4

Mishra S, Tiwary D, Ohri A (2018) Leachate characterisation and evaluation of leachate pollution potential of urban municipal landfill sites. Int. J. Environ. Waste Manag. 21, 217. https://doi.org/10.1504/ijewm.2018.093431

Naveen BP, Mahapatra DM, Sitharam TG, Sivapullaiah PV, Ramachandra TV (2017) Physico-chemical and biological characterization of urban municipal landfill leachate. Environ. Pollut. 220, 1-12. https://doi.org/10.1016/j.envpol.2016.09.002

OECD (Organisation for Economic Co-operation and Development) (2008) Handbook on Constructing Composite Indicators: Methodology and User Guide. OECD.

Öman CB, Junestedt C (2008) Chemical characterization of landfill leachates - 400 parameters and compounds. Waste Manag. 28, 1876-1891. https://doi.org/10.1016/j.wasman.2007.06.018

Ott WR, Thorn GC (1976) Air Pollution Index Systems in the United States and Canada. J. Air Pollut. Control Assoc. 26, 460-470. https://doi.org/10.1080/00022470.1976.10470272

Ott WR (1978) Environmental Indices: Theory and Practice. Ann Arbor Science, Ann Arbor.

Rajoo KS, Karam DS, Ismail A, Arifin A (2020) Evaluating the leachate contamination impact of landfills and open dumpsites from developing countries using the proposed Leachate Pollution Index for Developing Countries (LPIDC). Environ. Nanotechnology, Monit. Manag. 14, 100372. https://doi.org/10.1016/j.enmm.2020.100372

Rani A, Negi S, Hussain A, Kumar S (2020) Treatment of urban municipal landfill leachate utilizing garbage enzyme. Bioresour. Technol. 297, 122437. https://doi.org/10.1016/j.biortech.2019.122437

Renou S, Givaudan JG, Poulain S, Dirassouyan F, Moulin P (2008) Landfill leachate treatment: Review and opportunity. J. Hazard. Mater. https://doi.org/10.1016/j.jhazmat.2007.09.077

Saaty TL (1977) A scaling method for priorities in hierarchical structures. J. Math. Psychol. 15, 234-281. https://doi.org/10.1016/0022-2496(77)90033-5

Schiopu AM, Gavrilescu M (2010) Options for the Treatment and Management of Municipal Landfill Leachate: Common and Specific Issues. Clean - Soil, Air, Water 38, 1101-1110. https://doi.org/10.1002/clen.200900184 
Schwarzbauer J, Heim S, Brinker S, Littke R (2002) Occurrence and alteration of organic contaminants in seepage and leakage water from a waste deposit landfill. Water Res. 36, 2275-2287. https://doi.org/10.1016/S0043-1354(01)00452-3

Sebastian RM, Kumar D, Alappat BJ (2019a) A technique to quantify incinerability of municipal solid waste. Resour. Conserv. Recycl. 140, 286-296. https://doi.org/10.1016/j.resconrec.2018.09.022

Sebastian RM, Kumar D, Alappat BJ (2019b) Identifying appropriate aggregation technique for incinerability index. Environ. Prog. Sustain. Energy 38. https://doi.org/10.1002/ep.13068

Sewwandi BGN, Takahiro K, Kawamoto K, Hamamoto S, Asamoto S, Sato H (2013) Evaluation of Leachate Contamination Potential of Municipal Solid Waste Dumpsites in Sri Lanka Using Leachate Pollution Index 2017.

Singh RP, Nath S, Prasad SC, Nema AK (2008) Selection of Suitable Aggregation Function for Estimation of Aggregate Pollution Index for River Ganges in India. J. Environ. Eng. 134, 689-701. https://doi.org/10.1061/(asce)0733-9372(2008)134:8(689)

Slack RJ, Gronow JR, Voulvoulis N (2005) Household hazardous waste in municipal landfills: Contaminants in leachate. Sci. Total Environ. https://doi.org/10.1016/j.scitotenv.2004.07.002

Soltani A, Hewage K, Reza B, Sadiq R (2015) Multiple stakeholders in multi-criteria decision-making in the context of municipal solid waste management: A review. Waste Manag. https://doi.org/10.1016/j.wasman.2014.09.010

Swamee PK, Tyagi A, (2007) Improved Method for Aggregation of Water Quality Subindices 220-225. Van Laarhoven PJM, Pedrycz W (1983) A fuzzy extension of Saaty. Fuzzy Sets Syst. 11, 229-241.

Umar M, Abdul Aziz H, Suffian Yusoff M (2010) Variability of Parameters Involved in Leachate Pollution Index and Determination of LPI from Four Landfills in Malaysia. Int. J. Chem. Eng. 2010. https://doi.org/10.1155/2010/747953

Wang H, Cheng Z, Yuan H, Zhu N, Lou Z, Otieno P (2020) Occurrence of banned and commonly used pesticide residues in concentrated leachate: Implications for ecological risk assessment. Sci. Total Environ. 710, 136287. https://doi.org/10.1016/J.SCITOTENV.2019.136287

Wang Q, Wang H, Qi Z (2016) An application of nonlinear fuzzy analytic hierarchy process in safety evaluation of coal mine. Saf. Sci. 86, 78-87. https://doi.org/10.1016/j.ssci.2016.02.012

Wang TC, Chen YH (2007) Applying consistent fuzzy preference relations to partnership selection. Omega 35, 384-388. https://doi.org/10.1016/j.omega.2005.07.007

Wang YM, Chin KS (2011) Fuzzy analytic hierarchy process: A logarithmic fuzzy preference programming methodology. Int. J. Approx. Reason. 52, 541-553. https://doi.org/10.1016/j.ijar.2010.12.004 


\section{$712 \quad$ Funding}

713

714

715

716

717

718 manuscript.

Wu C, Fang W (2011) Combining the Fuzzy Analytic Hierarchy Process and the fuzzy Delphi method for developing critical 751-768. https://doi.org/10.1007/s11135-010-9425-6

Xu Y, Zhou Y, Wang D, Chen S, Liu J, Wang Z (2008) Occurrence and removal of organic micropollutants in the treatment of landfill leachate by combined anaerobic-membrane bioreactor technology. J. Environ. Sci. 20, 1281-1287. https://doi.org/10.1016/S1001-0742(08)62222-6

Yan H, Cousins IT, Zhang C, Zhou Q (2015) Perfluoroalkyl acids in municipal landfill leachates from China: Occurrence, fate during leachate treatment and potential impact on groundwater. Sci. Total Environ. 524-525, 23-31. https://doi.org/10.1016/j.scitotenv.2015.03.111

Yap HY, Nixon JD (2015) A multi-criteria analysis of options for energy recovery from municipal solid waste in India and the UK. Waste Manag. 46, 265-277. https://doi.org/10.1016/j.wasman.2015.08.002

Yazıcı R, Sekman E, Top S, Varank G, Sinan Bilgili M (2012) Degradation of phenolic compounds in aerobic and anaerobic landfills: a pilot scale study. https://doi.org/10.1177/0734242X11411232

Zadeh LA (1965) Fuzzy sets. Inf. Control 8, 338-353. https://doi.org/10.1016/S0019-9958(65)90241-X

Zhang Q, Xia Z, Wu M, Wang L, Yang H (2017) Human health risk assessment of DDTs and HCHs through dietary exposure in Nanjing, China. Chemosphere 177, 211-216. https://doi.org/10.1016/J.CHEMOSPHERE.2017.03.003

\section{Statements and Declarations}

\section{Ethical Approval}

Not applicable

The authors declare that no funds, grants, or other support were received during the preparation of this

\section{Competing Interests}

The authors have no relevant funding financial or non-financial interest to disclose.

\section{Author Contributions}


720 Tribhuwan Singh Bisht: Methodology, Software, Formal Analysis, Investigation, Data Curation, Writing 721 Original Draft

722 Dinesh Kumar: Conceptualization, Supervision, Validation, Writing - Review \& Editing, Visualization, 723 Resources

724 Babu J. Alappat: Conceptualization, Supervision, Writing - Review \& Editing, Visualization Resources 